\title{
MORTALITY IN MOSCOW AND OTHER MEGACITIES OF THE WORLD: SIMILARITIES AND DIFFERENCES*
}

\author{
EVGENY ANDREEV, EKATERINA KVASHA, TATIANA KHARKOVA
}

\begin{abstract}
This paper is devoted to the comparison of mortality by cause of death in Moscow and other megacities of the world since 1990. The selection of megacities was determined by the availability of detailed mortality data in the selected period. The objects of our comparison are data for Berlin, Hong Kong, London, Los Angeles, New York, Singapore, St. Petersburg, and Tokyo. Mortality from major groups of causes of death are considered, including cardiovascular diseases, neoplasms, external causes, diseases of the respiratory and digestive systems, infections and some others. The analysis uses standardised mortality rates by cause of death.

The mortality level in Moscow is significantly lower than in the majority of regions of Russia, but is still substantially higher than in foreign megacities. Due to a big lag at the beginning of the period, the mortality level in Moscow nowadays is higher than in all selected foreign megalopolises in the year 2000. Where Moscow's mortality level lags most behind others is in mortality from circulatory diseases and external causes. Moscow's successes in reducing mortality in 2000-2014 are very impressive. However, it is difficult to predict how events will unfold in the deteriorating economic situation.
\end{abstract}

Key words: Moscow, mortality, causes of death, megacities, circulatory diseases, external causes, neoplasms.

Compared with mortality trends in the rest of Russia, the situation in Moscow now looks very favourable. In the early 1990s, the standardised death rate (SDR) ${ }^{1}$ of both men and women in Moscow was almost no different from the rates in other urban settlements of the Central Federal District (CFD) and in St. Petersburg (Figure 1). On average, for the years 1990-1994 the SDR in Moscow was only 3-4\% lower among men, and among women even higher by almost 3\% in comparison with other cities of the Central Federal District, but 3.5\% lower than in St. Petersburg. Over the next four years, until 1998, the dynamics and level of mortality in the two capitals nearly matched, but then their paths diverged. In Moscow, mortality continued to decrease among both men and women, while in St. Petersburg and in the other cities of the Central Federal District, as well as in the country as a whole, an increase in mortality was observed, with a decline beginning only in 2004.

Evgeny M. Andreev, New Economic School, Russia.

Ekaterina A. Kvasha, National Research University Higher School of Economics, Russia.

TAtiana L. Kharkova (tkharkova@hse.ru), NATIONAL RESEARCH University Higher SchOOL OF EcONOMics, RUSSIA.

* The original article in Russian was Published in Demographic Review, 2016, 3(3): 39-79.

URL: HTTPS://DEMREVIEW.HSE.RU/2016--3/196884296.HTML.

THE RESULTS OF THE PROJECT “DEMOGRAPHIC DEVELOPMENT IN RUSSIA IN 2005-2015 IN THE CONTEXT OF LONG-TERM TRENDS", CARRIED OUT WITHIN THE FRAMEWORK OF THE BASIC RESEARCH PROGRAMME AT THE NATIONAL RESEARCH UNIVERSITY HIGHER SCHOOL OF ECONOMICS (HSE) IN 2016, ARE PRESENTED IN THIS PAPER.

\footnotetext{
${ }^{1}$ Here and below, the standard population of 1976 [Waterhouse et al. 1976] is used for calculating standardised indicators.
} 
As a result, the gap between Moscow and other cities of the Central Federal District (CFD) and St. Petersburg became more significant. So, if in 2000 in Moscow the SDR was lower than in St. Petersburg by $18 \%$ among men and $13 \%$ among women, and in comparison with the cities of the CFD without Moscow by 29\% and 18\% respectively, then in 2014 the gap increased accordingly to $21 \%$ and $45 \%$ for males and $15 \%$ and $30 \%$ for women.

The dynamics of the SDR for women in the cities of the CFD, with the exception of Moscow, are indistinguishable from those in Russia as a whole, while male mortality in the country as a whole is slightly lower than for the Central Federal District. By the end of the period here being considered - i.e. by 2014 - the SDR in Moscow was, relative to the rest of Russia, 1.7 times lower among men and 1.4 times lower among women. If you exclude the North Caucasus republics, where mortality data are still questionable, you will find that Moscow has had the lowest SDR among the regions of Russia since the second half of the 1990s (1997 for men and 1999 for women).

For almost the entire period since 1990, mortality trends in Moscow have been much more favourable than in most Russian regions. On the whole, however, these are the results of the same factors as for the trends in all of Russia. After a significant fall in the level of mortality in the country during the anti-alcohol campaign, by the late 1980s its slow growth had already begun. This growth accelerated in the early 1990s, when the campaign was completely stopped and there was a significant drop in life expectancy, the lowest point of which was recorded in 1994. By 1998, the level of mortality in the country had decreased, but remained significantly higher than in 1990 . Then, against the backdrop of the 1998 financial crisis, there was renewed growth, which lasted until 2003. Increased mortality after 1998 is usually associated with the financial crisis, but there is no widely accepted explanation of the reasons for its decline between 1994 and 1998 and its growth between 1998 and 2003 [Vishnevsky 2006: 293-323; Shkolnikov et al. 2014]. After 2003, a steady decline in mortality across the country began and continues to the present time, though it has slowed down considerably in the new economic crisis [Andreev and others in 2015; Shkolnikov et al. 2014; Andreev, Kvasha, Kharkova 2013].

The main difference between the dynamics of mortality in Moscow and trends in other Russian regions (Figure 1) is that, after the peak in 1994, the subsequent falls in mortality were quite moderate; since 2001, that is, three years before the rest of the country, a steady decline began.

However great Moscow's success may look in the Russian context, relative to EU-152 megacities mortality in Moscow remains high, although in the last twenty years it has come closer to theirs, especially for women. In 1995, relative to the average for the EU-15 countries, the SDR in Moscow was 2.2 times higher for men and 1.9 times for women, and in 2013 it was 1.5 and 1.1 times higher, respectively. A different picture is observed when comparing the average SDR in Moscow with that of the "new" EU member states ${ }^{3}$. Until 2010, the SDR in Moscow was higher than in the 12 new EU countries, especially in the periods 1993-1995 and 2000-2003, when the

\footnotetext{
${ }^{2}$ Member state of the EU before May 2004: Austria, Belgium, Denmark, Finland, France, Germany, Greece, Ireland, Italy, Luxembourg, Netherlands, Portugal, Spain, Sweden, United Kingdom.

${ }^{3}$ Member state of the EU after May 2004: Bulgaria, Cyprus, Czech Republic, Estonia, Hungary, Latvia, Lithuania, Malta, Poland, Romania, Slovakia, Slovenia.
} 
differences for men were $42-53 \%$ and $21-23 \%$, and the differences for women were $20-25 \%$ and 16-17\%. However, since 2011, mortality in Moscow among both men and women has become somewhat lower than in the 12 new EU countries.

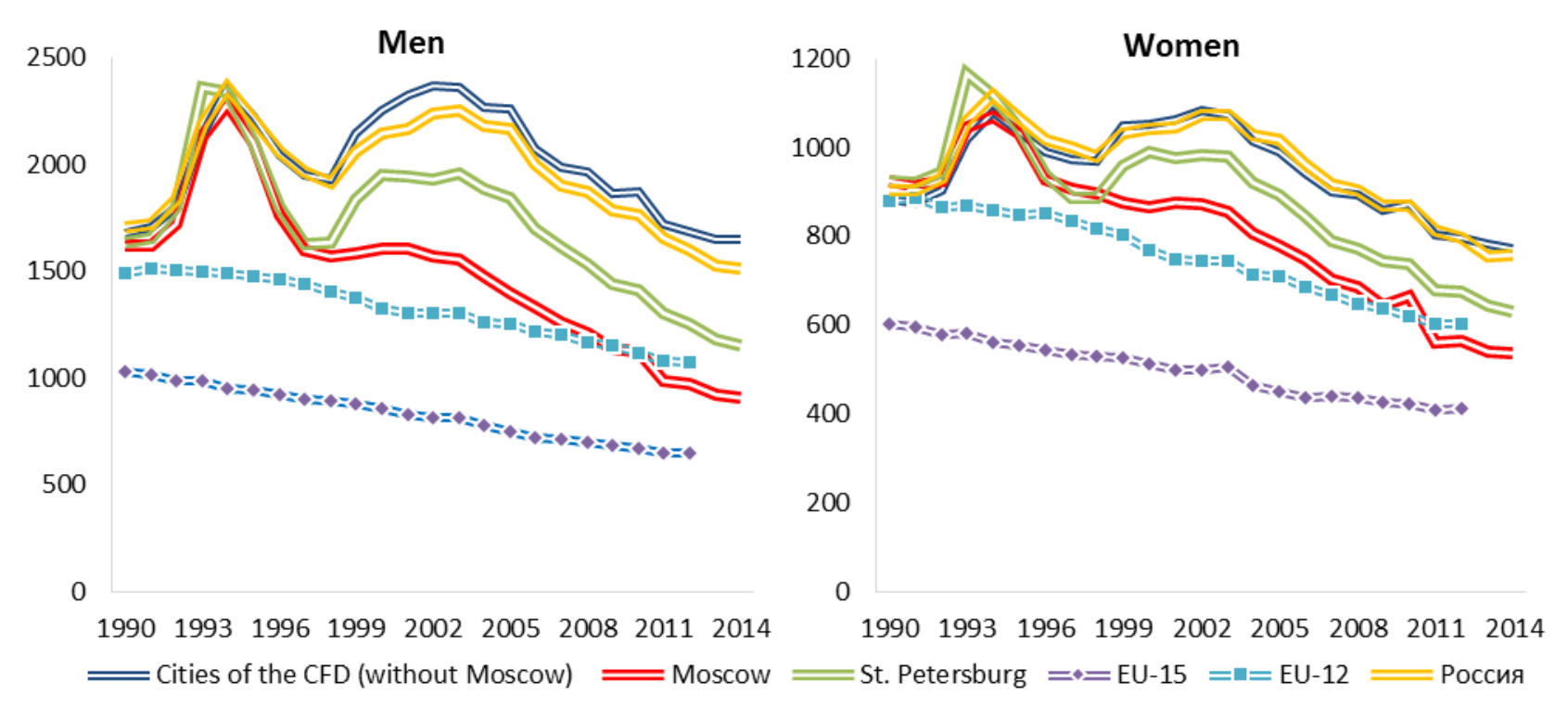

Figure 1. Standardised death rates from all causes of death in Moscow, the urban population of the CFD without Moscow, St. Petersburg and the EU-15, 1990-2014, per 100,000

Moscow is not only the capital of Russia, but also one of the largest cities in the world [UN 2015]. In 2014, Moscow ranked $21^{\text {st }}$ among the largest metropolitan areas of the world, so it was logical to compare the mortality rate in Moscow with mortality in other major metropolitan areas.

\section{DATA}

In selecting cities for comparison, priority was given to population size and the availability of high-quality statistical and demographic data. In particular, the choice of cities for comparison was determined by the availability in open sources of standardised death rates or distributions of numbers of deaths by age, sex and cause of death. The resulting selection included metropolitan areas located in different parts of the world, as well as Russia's second biggest metropolis after Moscow - St. Petersburg (Table 1).

We compare the data over 4 years: 1990 (or the first year following it for which data are available), 2000, 2010 and 2013 (or the latest year for which data are available).

A comparative analysis is carried out both by major classes of causes of death and by certain important groups of causes within the classes that determine the main changes in overall mortality.

Unfortunately, data on all causes of death under consideration are not available for all selected cities (megacities). Therefore, for several cities only certain causes will be analysed. 
Table 1: Megacities selected for comparison with Moscow

\begin{tabular}{|c|c|c|c|c|}
\hline City & Evaluation date & $\begin{array}{l}\text { Population } \\
\text { size, million } \\
\text { persons } \\
\end{array}$ & Source & Internet address \\
\hline Berlin & 31.12.2014 & 3.5 & $\begin{array}{l}\text { The Information System of the } \\
\text { Federal Health Monitoring }\end{array}$ & $\begin{array}{l}\text { http://www.gbe- } \\
\text { bund.de/gbe10/pkg_isgbe5.prc_ } \\
\text { isgbe?p_uid=gast\&p_aid=0\&p_ } \\
\text { sprache=E }\end{array}$ \\
\hline Hong Kong & 2013 & 7.2 & WHO Mortality Database & $\begin{array}{l}\text { http://www.who.int/healthinfo/ } \\
\text { mortality_data/en// }\end{array}$ \\
\hline London & $\begin{array}{l}\text { Average annual } \\
\text { population } 2012\end{array}$ & 8.3 & $\begin{array}{l}\text { GBD Compare - Public } \\
\text { Health England | Viz Hub }\end{array}$ & $\begin{array}{l}\text { http://vizhub.healthdata.org/ } \\
\text { gbd-compare/england }\end{array}$ \\
\hline Los Angeles & 2014 & 3.9 & $\begin{array}{l}\text { Los Angeles County } \\
\text { Department of Public Health }\end{array}$ & $\begin{array}{l}\text { http://www.publichealth. } \\
\text { lacounty.gov/index.htm }\end{array}$ \\
\hline Moscow & $\begin{array}{l}\text { Average annual } \\
\text { population } 2014\end{array}$ & 12.2 & Rosstat* & http://www.gks.ru/ \\
\hline New York & 2013 & 8.4 & $\begin{array}{l}\text { New York State Department } \\
\text { of Health Vital Statistics }\end{array}$ & $\begin{array}{l}\text { http://www.health.ny.gov/ } \\
\text { statistics/vital_statistics/ } \\
\text { index.htm }\end{array}$ \\
\hline St. Petersburg & $\begin{array}{l}\text { Average annual } \\
\text { population } 2014\end{array}$ & 5.2 & Rosstat* & http://www.gks.ru/ \\
\hline Singapore & 2013 & 3.8 & WHO Mortality Database & $\begin{array}{l}\text { http://www.who.int/ } \\
\text { healthinfo/mortality_data/en/ }\end{array}$ \\
\hline Tokyo & 01.10 .2014 & 13.4 & $\begin{array}{l}\text { Tokyo Statistical Yearbook } \\
\text { for 1990, 2000, } 2010 \text { and } 2013 \\
\text { Portal Site of Official } \\
\text { Statistics of Japan: Population } \\
\text { by Age (5-Year Age Group) } \\
\text { and Sex for Prefectures - Total } \\
\text { Population, October 1, } 2013\end{array}$ & $\begin{array}{l}\text { http://www.e- } \\
\text { stat.go.jp/SG1/estat/ } \\
\text { ListE.do?lid=000001118081 }\end{array}$ \\
\hline
\end{tabular}

Note: We present the population size of the city itself, rather than the urban agglomeration. References to the sources indicated in the table hereinafter are not repeated.

*Rosstat - Russian Federal State Statistics Service.

\section{GENERAL TRENDS IN MORTALITY AND STRUCTURE OF MORTALITY BY CAUSE OF DEATH}

Until the late 1990s, mortality dynamics in Moscow and St. Petersburg were similar (Figure 2), although fluctuations in mortality in St. Petersburg were great. But since the beginning of 2001, the differences in dynamics have been quite significant. Figure 2 shows that mortality indicators for inhabitants of Moscow barely responded to the economic crisis of 1998, while in St. Petersburg the increase in mortality was considerable. In Moscow, the SDR for men from 1998 to 2000 increased by 38 per 1,000 persons, and in St. Petersburg by 312. In Moscow, the SDR for women in general fell by 31 per 1,000, while in St. Petersburg there was an increase of 104 per 1,000. 


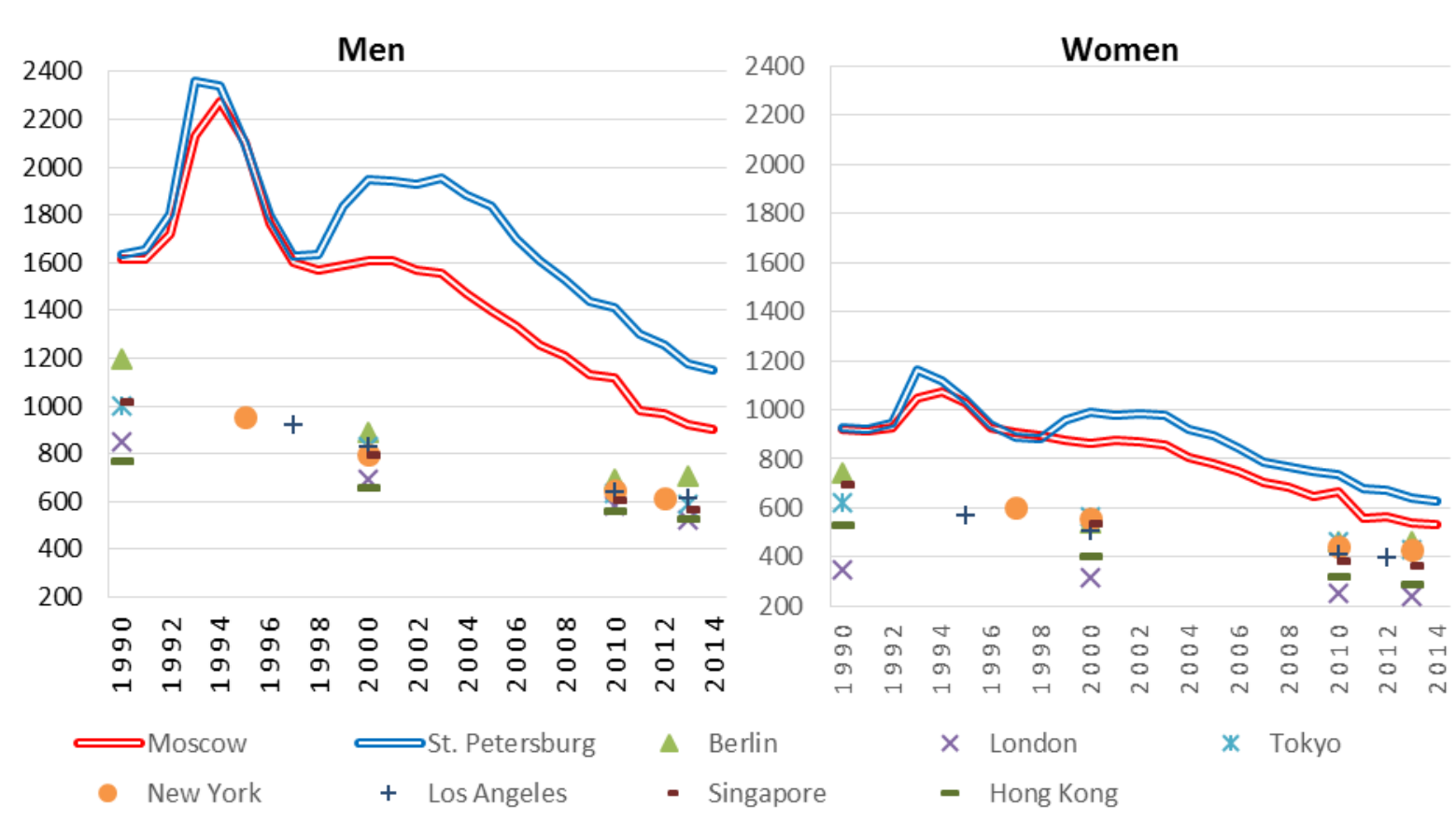

Figure 2. Standardised death rates in metropolitan areas 7 megacities, 1990-2014, per 100,000

As a result, over almost a quarter of a century (1990 to 2014) the SDR in Moscow decreased 1.8 times for men and 1.7 times for women. In St. Petersburg, the decline was 1.4 and 1.5 times, respectively. Is this a lot or a little, and how did Moscow's place in terms of its SDR level change in comparison with the other megacities examined here?

In Table 2 and Figure 2, it is evident that the level of mortality in Moscow at the beginning and end of the period lags far behind all the foreign cities considered. The standardised death rate in Moscow exceeds the corresponding figures of other megacities by 1.5-2 times. After 2000, the gap began to shrink. In 2013, compared to 1990, the gap in mortality rates between Moscow and other megacities (except Singapore) had slightly decreased for both men and women, although in the early 2000s it even slightly increased and still remains quite high (Figure 3).

Table 2. Standardised death rates in some megacities, 1990, 2000, 2010, 2013, per 100,000

\begin{tabular}{l|r|r|r|r|r|r|r|c}
\hline \multirow{2}{*}{ Megacity } & \multicolumn{4}{|c|}{ Men } & \multicolumn{4}{c}{ Women } \\
\cline { 2 - 9 } & $1990 *$ & 2000 & 2010 & $2013 * *$ & $1990 *$ & 2000 & 2010 & $2013 * *$ \\
\hline Berlin & 1197.6 & 890.4 & 696.1 & 707.6 & 744.8 & 538.1 & 463.9 & 460.4 \\
Hong Kong & 852.7 & 690.7 & 580.9 & 523.3 & 531.1 & 405.1 & 325.4 & 293.6 \\
London & 1001.6 & 833.5 & 635.7 & 589.0 & 348.0 & 315.6 & 253.8 & 240.6 \\
Los Angeles & 956.0 & 798.5 & 649.3 & 614.4 & 570.7 & 510.2 & 411.2 & 398.2 \\
Moscow & 1617.2 & 1605.3 & 1120.5 & 922.2 & 922.9 & 864.4 & 664.7 & 541.0 \\
New York & 918.6 & 833.5 & 642.4 & 611.5 & 603.8 & 561.3 & 446.3 & 433.1 \\
St. Petersburg & 1632.4 & 1947.2 & 1409.0 & 1176.2 & 924.0 & 988.7 & 738.7 & 642.9 \\
Singapore & 1017.0 & 797.0 & 609.8 & 566.0 & 699.3 & 538.3 & 385.6 & 366.3 \\
Tokyo & 770.9 & 657.9 & 562.9 & 528.5 & 619.0 & 562.6 & 460.8 & 428.3 \\
\hline
\end{tabular}

Note: Los Angeles 1995, New York 1997, Los Angeles 2012. 


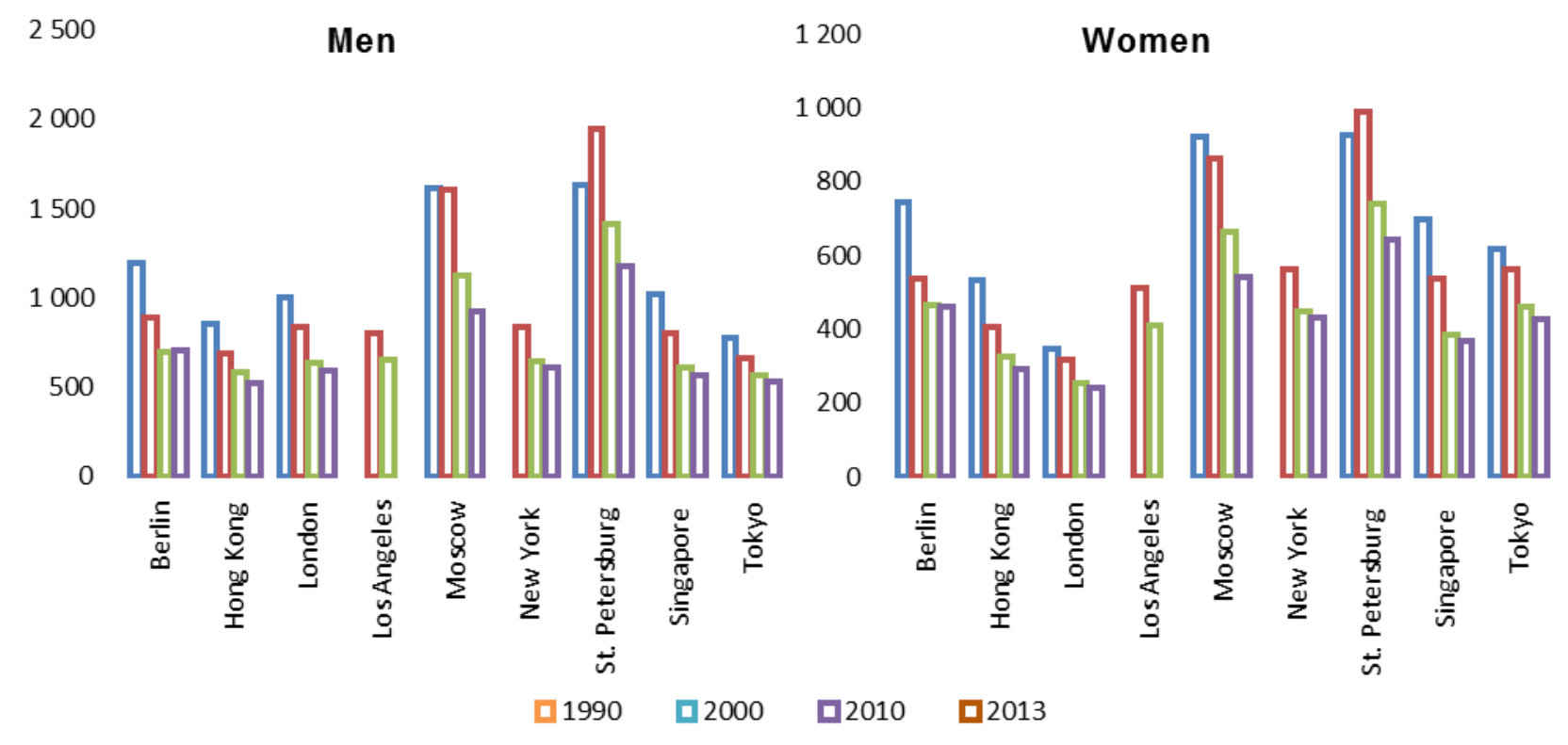

Figure 3. Standardised death rates in 7 megacities, 1990, 2000, 2010, 2013

Note: Los Angeles 1995, New York 1997, Los Angeles 2012.

So which causes of death distinguish mortality in Moscow from that of other megacities, which causes in the last 25 years have determined the reduction in mortality in Moscow, and due to what causes has mortality in other megacities been falling?

On the whole, for the period under consideration the main classes of causes of death in Moscow, as well as their ranking in importance, have not changed (Figure 4).

Throughout the entire period, the largest contribution to mortality in Moscow among both men and women came from diseases of the circulatory system (DCS). Over 25 years, the share of this class decreased somewhat (by 7.5 percentage points for men and 7.3 points for women). Second place among both men and women belongs to neoplasms. Moreover, for women the contribution of this class to total mortality increased by 3.8 percentage points by 2014 . In third place in Moscow comes "external causes of death", whose share remained fairly stable. Calling for special attention is the collective group of causes "Other causes", which includes all other classes not detailed on Figure 4. The contribution of this group of causes to the SDR grew 2 times for men and 1.5 times for women. A significant proportion of the group, especially in Moscow and Berlin, is represented by the class "symptoms, signs and ill-defined conditions", including such causes of death as senility, sudden infant death syndrome, death from unknown causes and other symptoms and ill-defined conditions. Beginning in 2012, in Moscow the diagnosis "symptoms and ill-defined conditions" came to be more widely used when coding the cause of death; as a result, in 2013-2014 the SDR from unidentified causes among both men and women became even greater than from external causes. Given the level of pathological anatomical service in Moscow, we are inclined to assume that such a relationship can only be explained by the fact that the category "symptoms, signs and abnormal clinical and laboratory findings, not elsewhere classified" is often replaced by another, usually "injuries with unknown intent". 


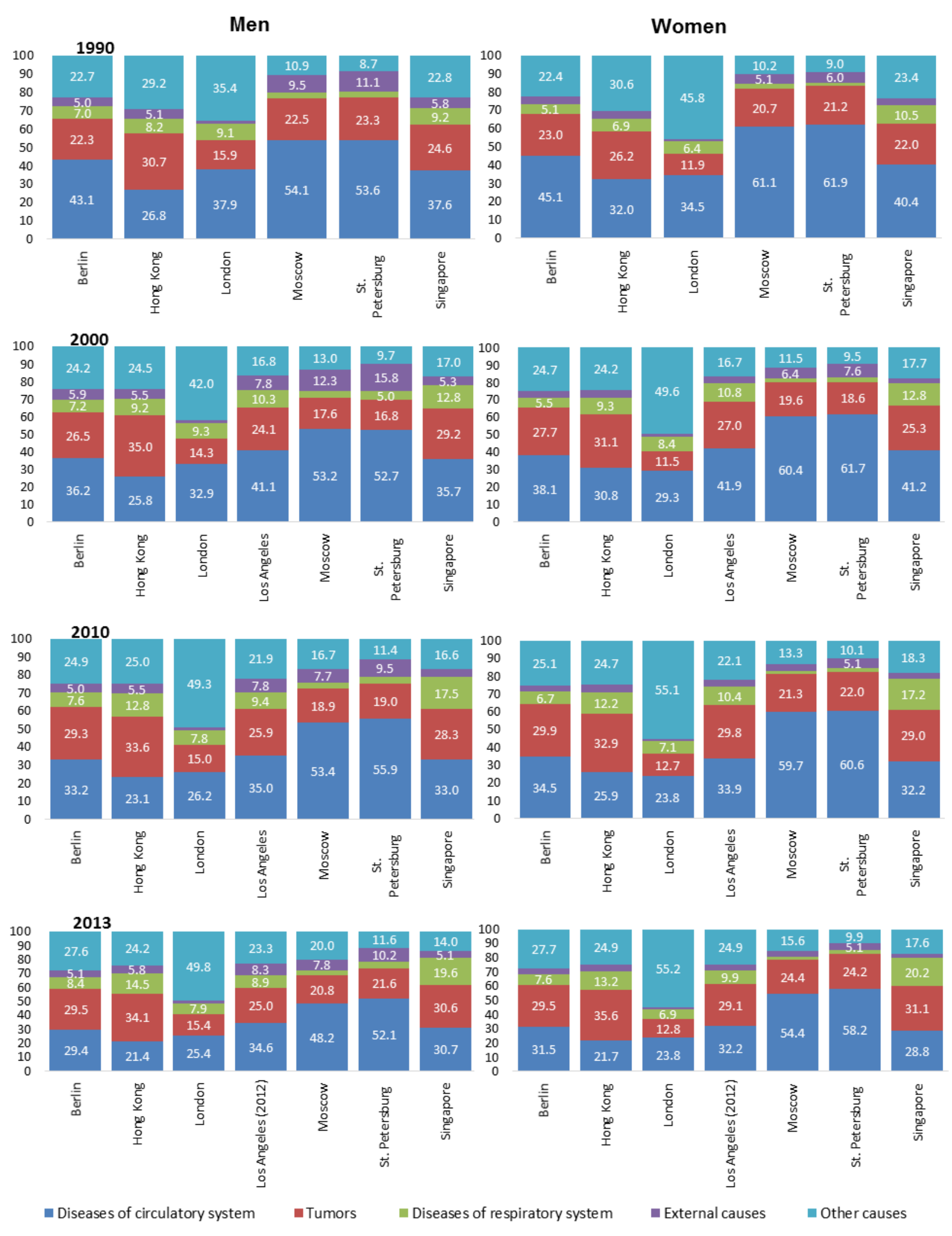

Figure 4. Structure of the standardised death rates by cause of death in 7 megacities, 1990, 2000, 2010, 2013, \%

A comparison of mortality patterns by cause of death in Moscow and in selected megacities makes it clear that there are both similarities and differences among them (Figure 4). Everywhere, except in Hong Kong, most of the deaths are attributable to diseases of the circulatory system, with 
neoplasms coming in second place. Moreover, the proportion of DCS is gradually decreasing, and that of neoplasms increasing. But there is not a single foreign megacity where the share of DCS has ever exceeded 50\%. In all the foreign megacities examined here, however, in third place comes not external causes, but diseases of the respiratory system.

\section{MORTALITY BY CAUSE OF DEATH}

\section{Diseases of the circulatory system}

The overwhelming majority of deaths in Moscow are attributable to deaths from diseases of the circulatory system. Although the share of this class of causes in the standardised death rate from all causes has been decreasing, by 2014 it accounted for more than half the SDR among women (54\%) and slightly less than half among men (47\%). Over the last quarter century, the SDR from diseases of the circulatory system in Moscow has decreased among men by 2.1 times, and among women by 2 times. The decline has not, however, been constant over the whole period. In the 1990s, there was a jump in mortality from DCS - rather sharp among men and milder among women (Figure 5) - and it was precisely this jump which led to the growth of total mortality in Moscow in the early 1990s. In subsequent years a slow decline was observed. The exception is 2010, when the rise in mortality, triggered by intense heat and smog in the summer months, caused a spike in the indicator for the whole year [Shaposhnikov et al. 2014].

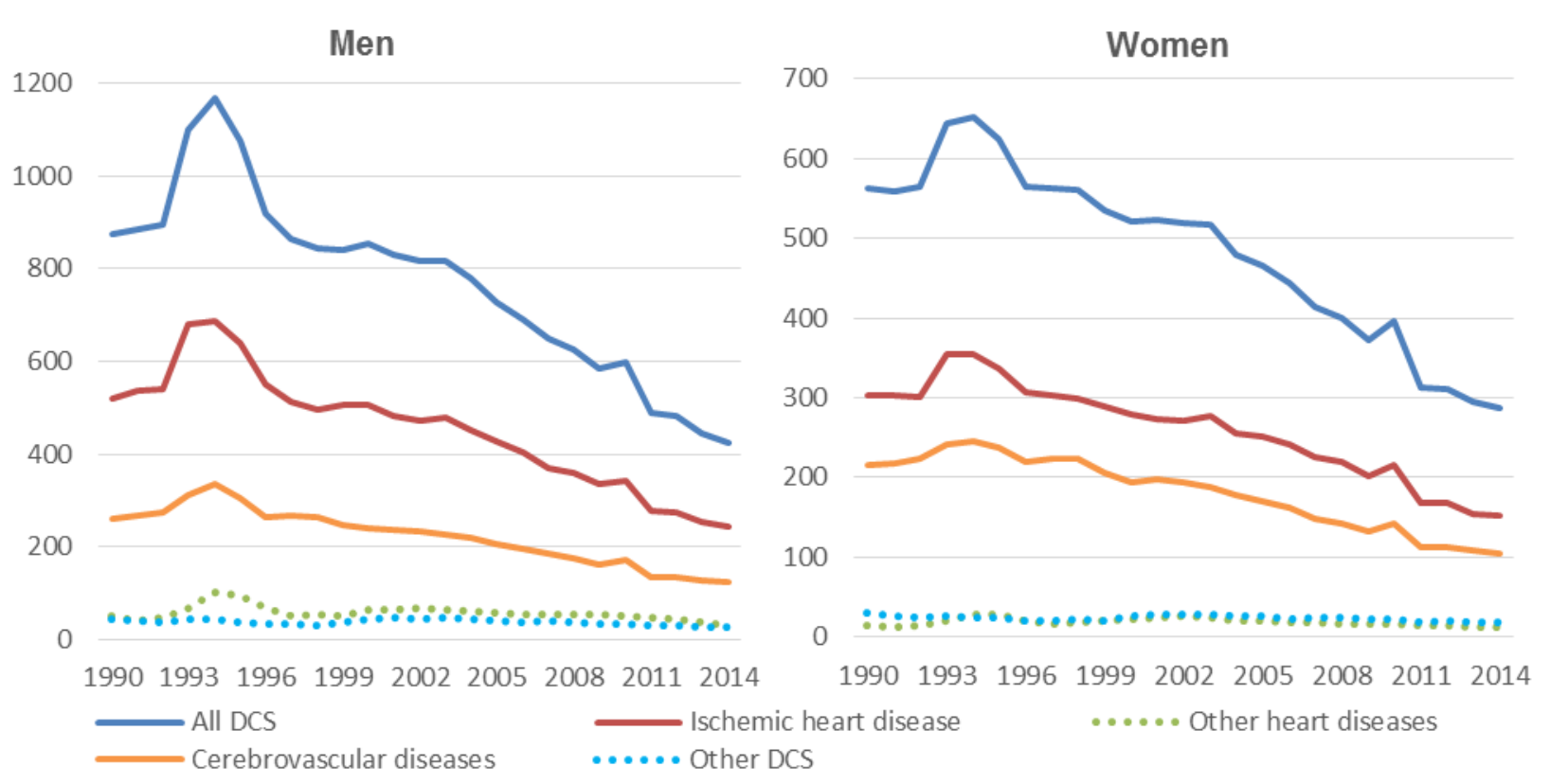

Figure 5. Standardised death rates by individual groups of diseases of the circulatory system and DCS in general, in Moscow, 1990-2014, per 100,000

Note: DCS - Diseases of the circulatory system.

The main contribution to mortality from diseases of the circulatory system comes from ischemic heart disease (Figure 5). Mortality from this cause has declined by about a factor of 2 over the last 25 years, but its contribution to total mortality from DCS has changed little and is 57$58 \%$ in men and $53-54 \%$ for women. 
The second main group of causes of death from DCS is cerebrovascular diseases (strokes). From 1990 to 2014, mortality from strokes decreased by 2.1 times, but its contribution in mortality from DCS has not changed the structure of mortality from DCS in Moscow, which remains relatively stable. In addition to the groups "ischemic heart disease" and "cerebrovascular disease", the cause "other heart diseases" is often singled out. It sometimes happens that a reduction in mortality from ischemic heart disease is accompanied by a simultaneous increase in mortality from other diseases of the heart, but most often this simply indicates a change in the diagnosis of the cause of death, rather than a real change in the balance of causes. In Moscow, mortality from "other diseases of the heart" has changed little since 1990.

In Russia as a whole and in most of its regions, including St. Petersburg, changes in mortality from DCS were less favourable. Its decrease in St. Petersburg began only after 2003, and was preceded by a notable increase in the SDR. In contrast to Moscow, the reduction in mortality from coronary heart disease was accompanied by an increased SDR from other heart diseases (Figure 6).

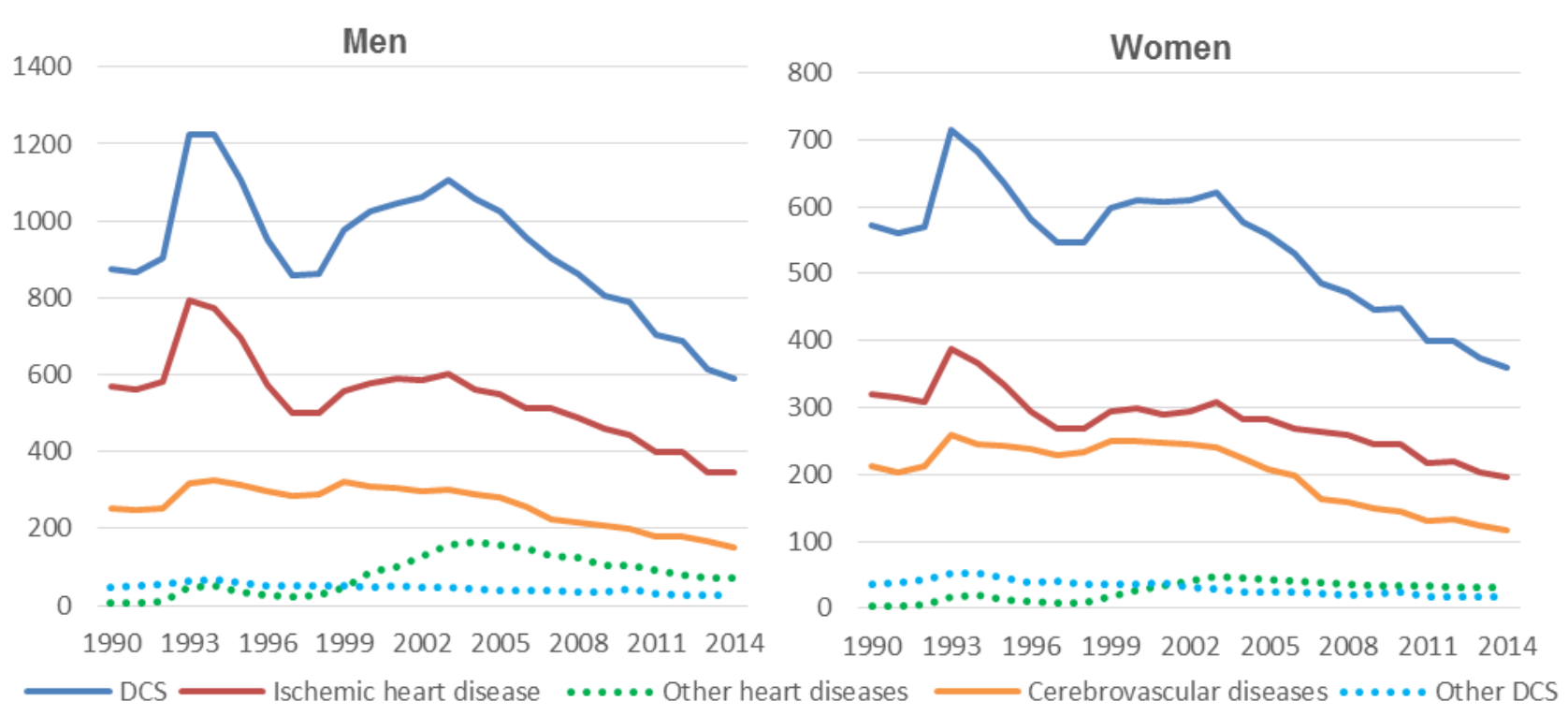

\section{Figure 6. Standardised death rates by selected groups of diseases of the circulatory system and DCS in general in St. Petersburg, 1990-2014, per 100,000}

Note: DCS - Diseases of the circulatory system.

Diseases of the circulatory system are the leading cause of death in all the selected megacities, but the level of mortality from DCS and from the causes included in this class is much lower than in Moscow, and even more so than in St. Petersburg and in Russia as a whole. At the same time, the pace of decline in mortality from DCS in Moscow has recently been comparable to other metropolitan areas under consideration, as shown in Table 3. So, for the period after 2000, the death rate from DCS among men in Moscow fell by 52\%, and in other megacities by 54-65\%, with the corresponding figures for women being $56 \%$ and $48-71 \%$. For coronary heart disease, the reduction in the SDR for men in Moscow was 50\%, and in other megacities 52-75\%, with the figures for women being $55 \%$ and $41-72 \%$, respectively. Finally, the reduction in mortality from cerebrovascular disease in men in Moscow was 52\%, and in other metropolitan areas 54-68\%, while for women it was $56 \%$ in Moscow and $47-78 \%$ in other megacities. 
Table 3. Standardised death rates from all diseases of the circulatory system, ischemic heart disease and cerebrovascular disease, in 9 megacities,

1990, 2000, 2010, 2013, per 100,000

\begin{tabular}{|c|c|c|c|c|c|c|c|c|}
\hline \multirow{2}{*}{ Megacity } & \multicolumn{4}{|c|}{ Men } & \multicolumn{4}{|c|}{ Women } \\
\hline & 1990* & 2000 & 2010 & $2013 * *$ & $1990 *$ & 2000 & 2010 & $2013 * *$ \\
\hline \multicolumn{9}{|c|}{ Diseases of the circulatory system } \\
\hline Berlin & 516.1 & 322.2 & 231.0 & 207.9 & 335.8 & 205.1 & 160.2 & 144.9 \\
\hline Hong Kong & 228.8 & 177.9 & 134.3 & 112.2 & 170.2 & 124.8 & 84.1 & 63.8 \\
\hline London & 379.8 & 274.5 & 166.5 & 149.4 & 213.6 & 164.6 & 109.6 & 101.9 \\
\hline Los Angeles & No data & 327.9 & 227.5 & 212.4 & No data & 214.0 & 139.4 & 128.2 \\
\hline Moscow & 874.8 & 853.3 & 597.9 & 444.1 & 563.5 & 521.8 & 397.0 & 294.4 \\
\hline New York & No data & No data & No data & No data & No data & No data & No data & No data \\
\hline St. Petersburg & 875.5 & 1026.0 & 788.3 & 613.4 & 571.9 & 610.4 & 447.8 & 374.0 \\
\hline Singapore & 382.8 & 284.7 & 201.2 & 173.7 & 282.7 & 221.7 & 124.3 & 105.6 \\
\hline Tokyo & No data & No data & No data & No data & No data & No data & No data & No data \\
\hline \multicolumn{9}{|c|}{ Ischemic heart disease } \\
\hline Berlin & 219.1 & 150.3 & 105.9 & 90.2 & 107.6 & 76.8 & 57.2 & 44.2 \\
\hline Hong Kog & 91.5 & 72.1 & 64.0 & 50.9 & 57.5 & 43.5 & 31.6 & 22.2 \\
\hline London & 268.4 & 188.2 & 109.5 & 97.7 & 127.8 & 97.1 & 58.7 & 54.0 \\
\hline Los Angeles & 269.4 & 217.0 & 137.1 & 126.1 & 164.8 & 129.9 & 72.7 & 63.7 \\
\hline Moscow & 518.7 & 504.6 & 342.7 & 252.9 & 303.4 & 279.5 & 216.4 & 154.5 \\
\hline New York & 355.0 & 321.1 & 212.7 & 189.3 & 246.1 & 220.9 & 146.3 & 130.6 \\
\hline St. Petersburg & 569.4 & 579.1 & 442.9 & 348.1 & 319.6 & 298.8 & 244.5 & 203.1 \\
\hline Singapore & 214.7 & 166.7 & 121.9 & 97.7 & 132.4 & 111.5 & 64.1 & 46.1 \\
\hline Tokyo*** & 143.9 & 93.6 & 77.6 & 70.2 & 92.2 & 56.4 & 45.0 & 40.7 \\
\hline \multicolumn{9}{|c|}{ Cerebrovascular diseases } \\
\hline Berlin & 90.0 & 45.0 & 34.7 & 29.7 & 72.5 & 32.9 & 27.9 & 24.3 \\
\hline Hong Kong & 78.6 & 64.1 & 40.6 & 35.2 & 67.0 & 48.0 & 28.2 & 23.1 \\
\hline London & 70.0 & 51.8 & 33.8 & 30.9 & 60.3 & 45.9 & 32.1 & 30.3 \\
\hline Los Angeles & 51.5 & 48.0 & 30.6 & 27.3 & 43.1 & 40.7 & 24.8 & 23.7 \\
\hline Moscow & 261.8 & 240.0 & 170.3 & 125.9 & 215.7 & 193.1 & 142.5 & 107.9 \\
\hline New York & 29.5 & 24.8 & 17.5 & 16.8 & 24.6 & 20.9 & 15.4 & 16.4 \\
\hline St. Petersburg & 254.0 & 310.5 & 200.0 & 166.6 & 212.9 & 248.8 & 145.1 & 123.4 \\
\hline Singapore & 113.1 & 71.9 & 45.7 & 44.2 & 103.8 & 73.9 & 37.7 & 37.5 \\
\hline Tokyo & 100.9 & 76.4 & 51.9 & 43.4 & 76.5 & 51.9 & 29.5 & 24.4 \\
\hline
\end{tabular}

Note: *Los Angeles 1995, New York 1997; **Los Angeles 2012; ***For Tokyo indicators are given for those dying from all heart disease, not only ischemic disease.

What distinguishes Moscow from other megacities of the world is that the level of mortality from cardiovascular disease is still quite significant, which is probably due to the general backwardness of Russian health care. For example, the developed countries have developed and now use everywhere extremely effective but expensive methods of treatment of stroke and poststroke rehabilitation. These methods, unfortunately, are not used by the Russian public health system, hence the above-noted difference between Moscow (Russian) and Western figures. And, of course, a very important factor is health-care spending, which, as we know, is currently shrinking.

\section{Neoplasms}

Mortality from neoplasms (mainly malignant neoplasms) is in second place in the structure of causes of death of Moscow inhabitants (for both men and women). The share of these causes in total mortality in 2014 was $21 \%$ in men and $25 \%$ women. The share of non-malignant neoplasms in Moscow, as well as in other cities, is small, and amounts to about $1 \%$ of all cancers in men and $1.5 \%$ for women. Therefore, it is usually mortality from malignant neoplasms that is analysed. 
Compared with other causes, the differences in this kind of mortality between Moscow and St. Petersburg and other selected megacities are not so great, and by 2013 these differences had even slightly decreased due to a slower decrease in the indicators in other cities. Also notable during the period under review was the convergence of men's and women's mortality rates due to the faster pace of its decline in men.

Table 4. Standardised death rates from neoplasms in 9 megacities, 1990, 2000, 2010, 2013, per 100,000

\begin{tabular}{l|r|r|r|r|r|r|r|r}
\hline \multirow{2}{*}{ Megacity } & \multicolumn{4}{|c|}{ Men } & \multicolumn{4}{c}{ Women } \\
\cline { 2 - 9 } & $1990 *$ & 2000 & 2010 & $2013 * *$ & $1990 *$ & 2000 & 2010 & $2013 * *$ \\
\hline Berlin & 267.2 & 235.6 & 203.7 & 208.6 & 171.4 & 149.1 & 138.9 & 135.9 \\
Hong Kong & 261.5 & 241.7 & 195.2 & 178.3 & 139.1 & 126.2 & 106.9 & 104.4 \\
London & 159.2 & 119.2 & 95.6 & 90.6 & 73.4 & 64.8 & 58.7 & 54.9 \\
Los Angeles & No data & 192.5 & 168.2 & 153.5 & No data & 137.7 & 122.4 & 115.9 \\
Moscow & 364.0 & 283.3 & 212.0 & 191.7 & 191.5 & 169.1 & 141.5 & 131.7 \\
New York*** & 210.7 & 192.9 & 161.8 & 151.2 & 151.5 & 140.7 & 118.7 & 112.5 \\
St. Petersburg & 380.3 & 328.0 & 268.1 & 254.6 & 196.3 & 184.2 & 162.6 & 155.6 \\
Singapore & 250.1 & 232.8 & 172.4 & 173.3 & 154.2 & 136.4 & 111.6 & 113.9 \\
Tokyo*** & 229.7 & 223.2 & 191.9 & 181.3 & 120.4 & 117.5 & 100.1 & 97.0 \\
\hline
\end{tabular}

Notes: *New York 1997; **Los Angeles 2012; ***Malignant neoplasms.

Although the standardised death rate from cancer in Moscow is lower than in St. Petersburg and Berlin, it is much higher than in the other megacities taken for comparison (Table 4).

As in other megacities, the structure of mortality from neoplasms in Moscow differs between men and women (Figure 7).
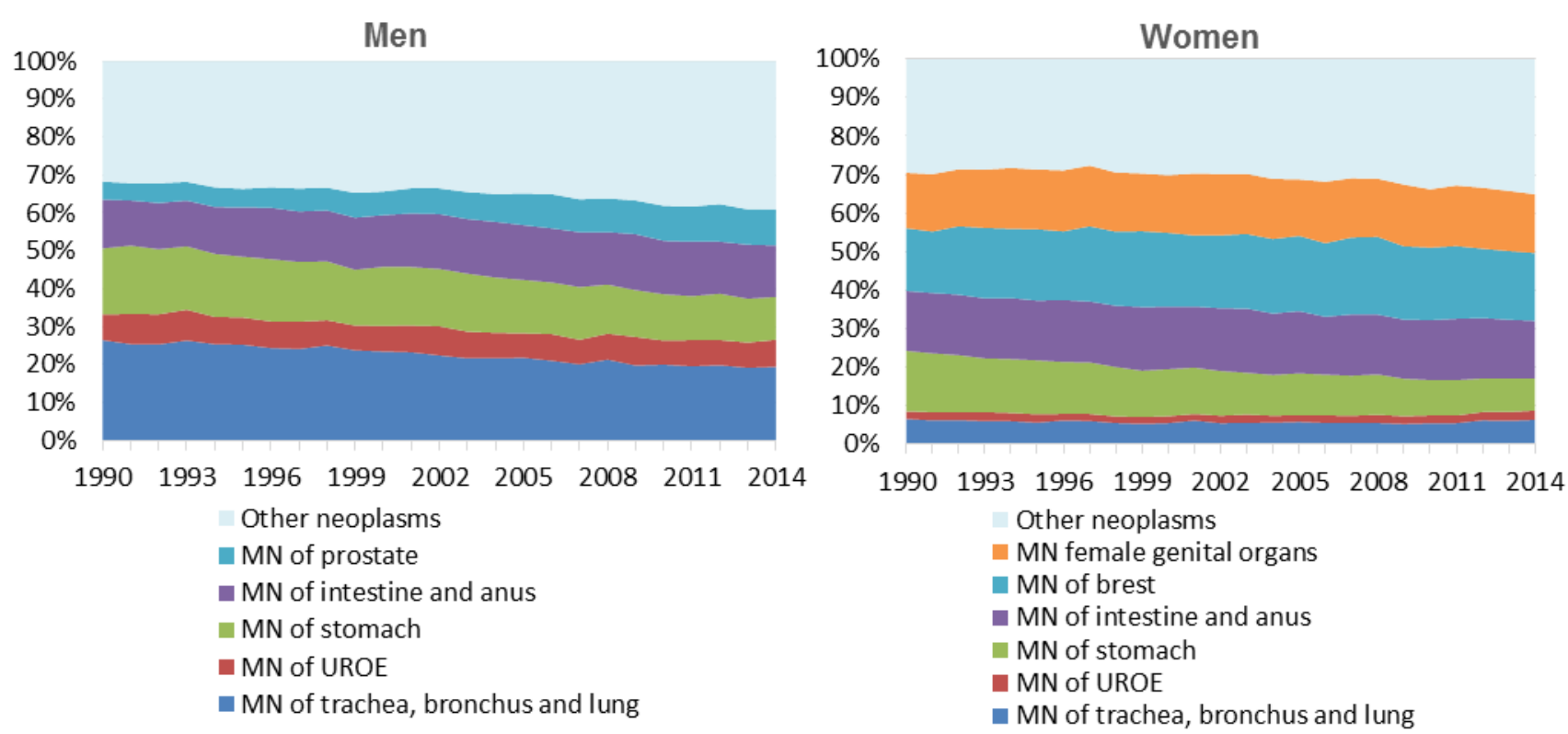

Figure 7. Structure of the standardised death rates from cancer in Moscow, 1990-2014, \%

Notes: MN-malignant neoplasms; MT UROE-malignant neoplasms of the upper respiratory organs and the esophagus; other neoplasms also include benign neoplasms.

Over the past 25 years, mortality from neoplasms has declined steadily in Moscow, decreasing by 1.9 times among men, and by 1.5 times among women (Figure 8 ). St. Petersburg 
too has seen a reduction in mortality from neoplasms, but the decline was much lower than in Moscow. As a result, the difference in mortality from neoplasms between the two Russian megacities has increased among both men and women.

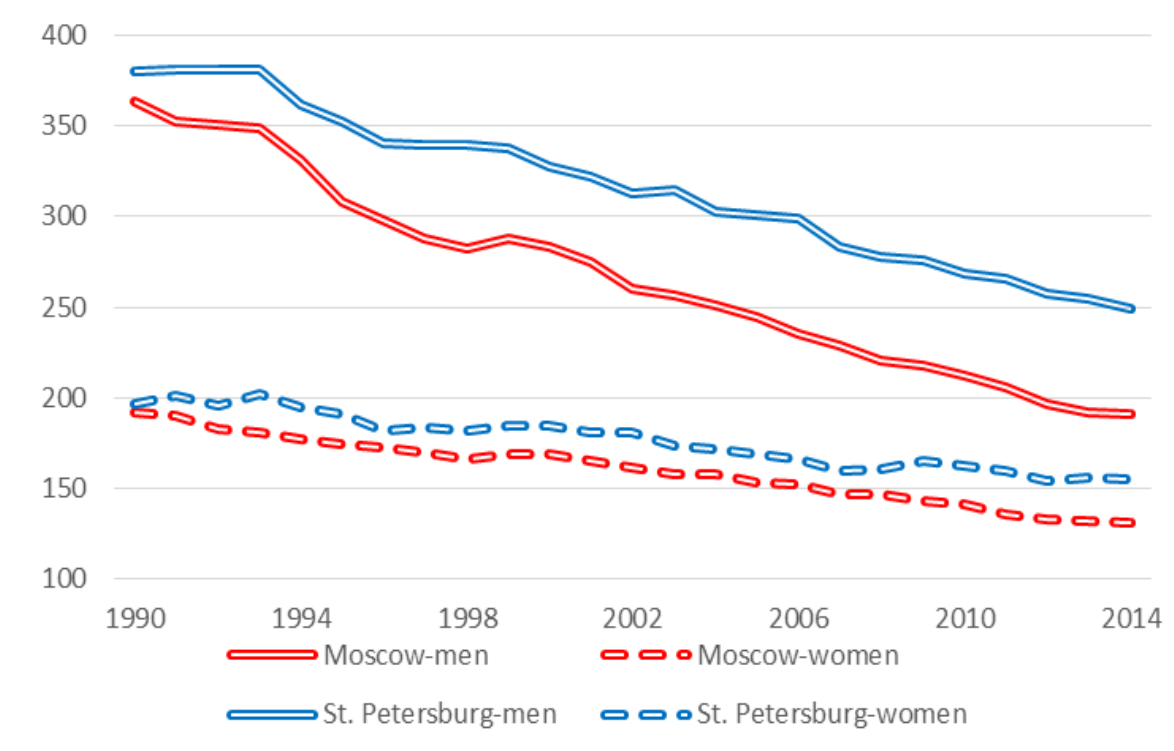

Figure 8. Standardised death rates from cancer in Moscow and St. Petersburg, 1990-2014, per 100,000

\section{Neoplasms of the respiratory organs and the esophagus}

Without including residual group of causes "other neoplasms", first place among all causes of male deaths belonging to the class of neoplasms (26.5\% in 2014) goes to malignant neoplasms of the respiratory system and the esophagus. Among women, this category is ranked third. In this group we have included two subgroups of causes of death: malignant neoplasms of the trachea, bronchi and lungs, and malignant neoplasms of the upper parts of the respiratory system and the esophagus.

In comparison with the other megacities under consideration, mortality from malignant neoplasms of the trachea, bronchi and lungs among women in Moscow looks favourable (Table 5). For men at the beginning of the reporting period, the death rate from this cancer site was higher than in all foreign megacities. By 2013, its level had dropped by more than 2.6 times and was one of the lowest in these cities. Mortality from malignant neoplasms of the upper parts of the respiratory system and the esophagus does not show such big differences.

Among men, the proportion of deaths from these two cancer sites relative to all neoplasms is gradually decreasing. This is mainly due to the decrease in mortality from cancer of the trachea, bronchi and lungs (Figure 9). Mortality from cancer of the upper sections of the respiratory organs and the esophagus in the last 5 years has not changed. Among women, with a much lower level of mortality from neoplasms of the trachea, bronchi and lungs, it stopped declining in the mid-2010s, and mortality from neoplasms of the upper parts of the respiratory system and the esophagus stabilised at the level of the mid-1990s. In 2014, however, an increase in mortality from these cancer sites was recorded, for both men and women. 
Table 5. Standardised death rates from cancer of the esophagus and respiratory organs in 7 megacities, 1990, 2000, 2010, 2013, per 100,000

\begin{tabular}{|c|c|c|c|c|c|c|c|c|}
\hline \multirow{2}{*}{ Megacity } & \multicolumn{4}{|c|}{ Men } & \multicolumn{4}{|c|}{ Women } \\
\hline & $1990 *$ & 2000 & 2010 & $2013 * *$ & $1990^{*}$ & 2000 & 2010 & $2013 * *$ \\
\hline \multicolumn{9}{|c|}{ Malignant neoplasms of the trachea, bronchi and lungs (C33.C34) } \\
\hline Berlin*** & 74.8 & 64.1 & 59.0 & 58.3 & 18.4 & 21.7 & 27.0 & 29.6 \\
\hline Hong Kong & 88.2 & 79.9 & 60.1 & 54.2 & 36.2 & 29.5 & 24.1 & 24.2 \\
\hline London & 86.7 & 58.9 & 43.7 & 41.0 & 27.9 & 25.2 & 24.1 & 22.9 \\
\hline Los Angeles & 63.5 & 52.6 & 39.7 & 33.5 & 32.5 & 28.0 & 23.8 & 21.5 \\
\hline Moscow & 96.2 & 66.3 & 42.3 & 36.6 & 12.5 & 9.2 & 7.6 & 8.0 \\
\hline St. Petersburg & 104.1 & 82.9 & 59.6 & 56.7 & 13.8 & 10.8 & 10.5 & 9.5 \\
\hline Singapore & 72.8 & 64.4 & 47.4 & 45.7 & 24.8 & 20.6 & 17.4 & 18.4 \\
\hline \multicolumn{9}{|c|}{ Malignant neoplasms of the upper respiratory organs and esophagus (COO-C15) } \\
\hline Berlin & 17.2 & 17.4 & 14.0 & 15.6 & 3.7 & 4.6 & 4.2 & 3.8 \\
\hline Hong Kong & 34.1 & 24.5 & 16.3 & 14.6 & 7.6 & 5.6 & 3.6 & 3.5 \\
\hline London & 14.0 & 14.1 & 12.5 & 11.7 & 4.9 & 4.7 & 4.1 & 3.9 \\
\hline Los Angeles & No data & 10.0 & 9.0 & 8.4 & $\ldots$ & 2.7 & 2.4 & 2.3 \\
\hline Moscow & 24.7 & 19.2 & 13.4 & 12.8 & 3.8 & 3.0 & 2.9 & 3.1 \\
\hline St. Petersburg & 31.0 & 28.3 & 22.7 & 18.0 & 6.2 & 4.4 & 4.0 & 3.4 \\
\hline Singapore & 31.9 & 21.8 & 14.5 & 14.1 & 9.6 & 5.4 & 3.8 & 3.2 \\
\hline
\end{tabular}

Notes: *Los Angeles 1995, **Los Angeles 2012.*** - in Berlin, also includes cancer of the larynx.

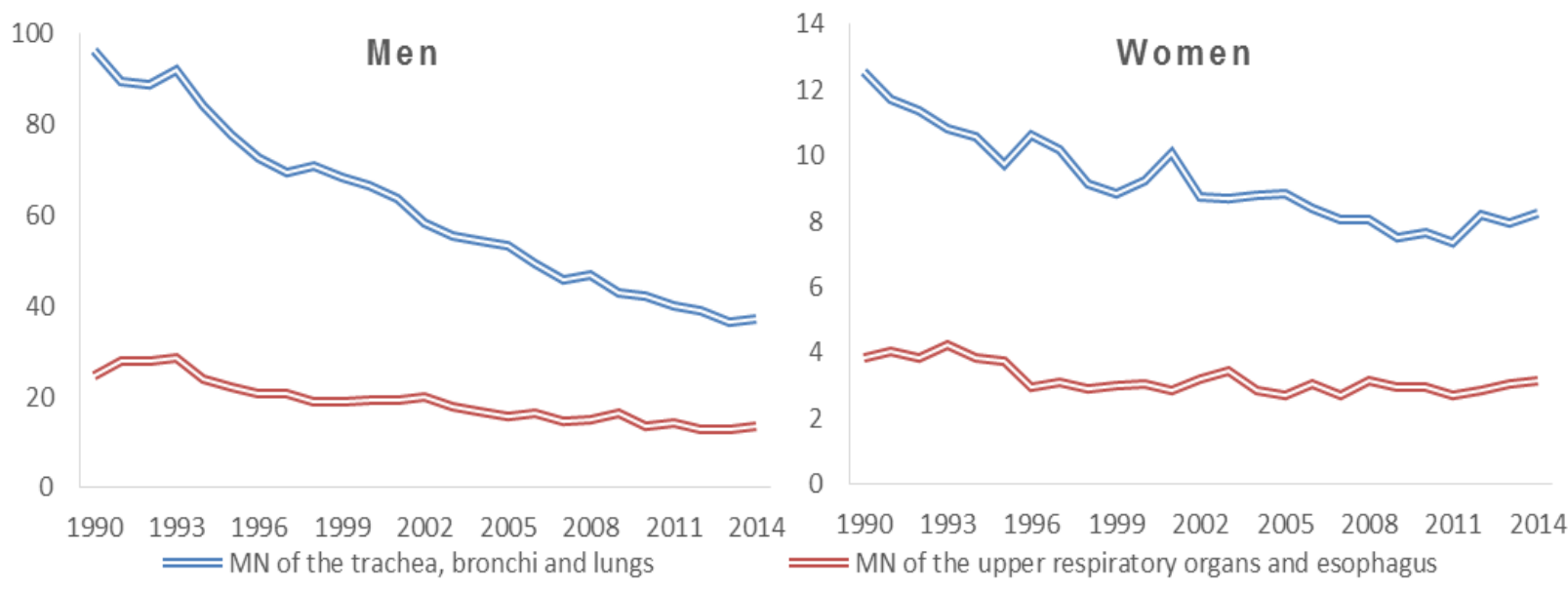

Figure 9. Standardised death rates from cancer of the esophagus and respiratory organs in Moscow, 1990-2014, per 100,000

In order to reduce mortality from cancer, it is important to detect the disease as soon as possible. Unfortunately, in Russia and its regions, including Moscow, almost half of the diagnoses in 2014 were made at stages III and IV of the disease [Kaprin et al. 2015: 23]. For cancer of the stomach, pancreas, liver, respiratory organs and esophagus, the proportion of diagnoses in the late stages was the highest [Kaprin et al. 2015: 60-149]. Our calculations, based on Ministry of Health data $^{4}$, show that in 2004 (the first year for which we have relevant data) the proportion of late diagnoses of malignant neoplasms of the trachea, bronchi and lungs was 67\%, and by 2014 (the last year for which we have data) it rose to $74 \%$. For cancer of the upper sections of the respiratory

\footnotetext{
${ }^{4}$ Here and below, data on the prevalence of neoplasms for the period until 2014 are taken from the state medical statistics (Form \# 35 "Information on patients with malignant neoplasms for ... year").
} 
organs and the esophagus, the proportion of late diagnoses in 2004 was even higher at $77 \%$, but over the next 10 years decreased to $71 \%$.

\section{Neoplasms of the female breast and genital organs}

Malignant neoplasms of the female breast and genital organs take first place in the structure of cancer mortality in women. In 2014 in Moscow, almost 33\% of all deaths from cancer among women were due to this cause (18\% for breast cancer and $15 \%$ for cancer of the genital organs). From 1990 to 2014, the dynamics of mortality from breast cancer among women, despite a tendency to decrease, were not uniform. During all the 1990s and the first half of the 2000s, significant fluctuations were observed in mortality from this cause, and only since the late 2000s has there been a steady decline (Figure 10).

Mortality from malignant neoplasms in both sites has almost always been slightly lower in Moscow than in St. Petersburg, but Moscow loses to foreign metropolises, particularly in mortality from malignant neoplasms of the female genital organs (Table 6). Standing out among all the megacities here considered is London, where the death rate from cancer of these sites, as opposed to malignant neoplasms of the respiratory system and the esophagus, is very low.

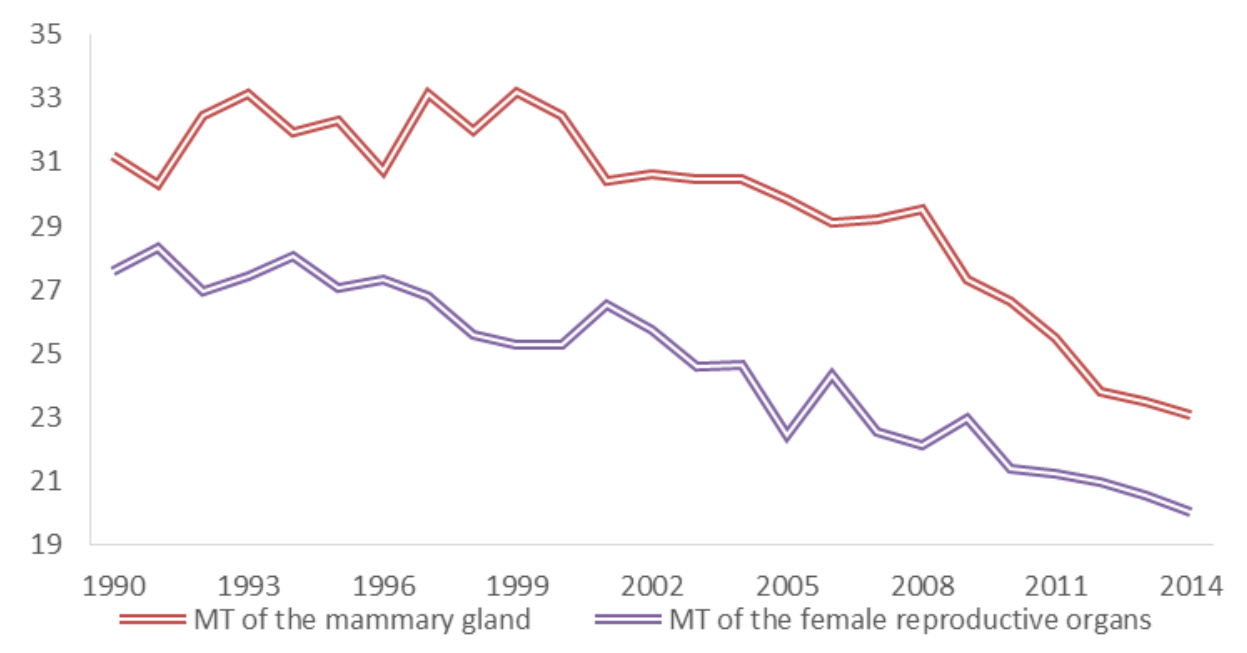

Figure 10. Standardised death rates from malignant neoplasms of the female breast and genital organs in Moscow, 1990-2014, per 100,000

Table 6. Standardised death rates from malignant neoplasms of female breast and genital organs in 7 metropolitan areas, 1990, 2000, 2010, 2013, per 100,000

\begin{tabular}{|c|c|c|c|c|c|c|c|c|}
\hline \multirow{3}{*}{ Megacity } & \multicolumn{8}{|c|}{ Malignant neoplasms } \\
\hline & \multicolumn{4}{|c|}{ Female breast (C50) } & \multicolumn{4}{|c|}{ Female genital organs (C51-C58) } \\
\hline & $1990 *$ & 2000 & 2010 & $2013 * *$ & $1990 *$ & 2000 & 2010 & $2013 * *$ \\
\hline Berlin & 30.5 & 27.7 & 22.5 & 22.7 & 20.2 & 15.4 & 11.8 & 13.4 \\
\hline Hong Kong & 12.0 & 11.8 & 12.2 & 11.9 & 12.1 & 9.3 & 9.8 & 9.9 \\
\hline London & 11.2 & 9.3 & 7.5 & 6.8 & 5.6 & 4.9 & 4.0 & 3.8 \\
\hline Los Angeles & 28.5 & 22.8 & 20.2 & 20.0 & No data & 17.0 & 15.5 & 14.3 \\
\hline Moscow & 31.2 & 32.5 & 26.6 & 23.5 & 27.6 & 25.3 & 21.4 & 20.6 \\
\hline St. Petersburg & 28.6 & 32.2 & 30.8 & 27.4 & 28.9 & 27.2 & 26.5 & 27.1 \\
\hline Singapore & 20.0 & 18.8 & 19.0 & 20.8 & 16.9 & 16.1 & 12.3 & 12.6 \\
\hline
\end{tabular}

Notes: *Los Angeles 1995, New York 1997; **Los Angeles 2012. 
Unlike St. Petersburg, where the indicators have barely changed at all, in Moscow mortality from neoplasms of the two groups has decreased by 1.4 times over the last 25 years, with the main decline occurring in the past few years.

In Moscow, the reduction in mortality from breast cancer is accompanied by an increase in the number of diseases of this form of cancer. "These 'scissors' between the number of cases and deaths is definitely positive, and quite rare among the health indicators of the population of Russia" [Revich et al. 2014]. Yet in Moscow a large proportion of cancers of this site are detected only at stages III and IV: in 2014, the figure was 31\% (34\% in 2004), indicating a lack of effective prevention systems [Kaprin et al. 2015: 10-12]. On the other hand, the number of X-ray preventive breast examinations in Moscow has grown in recent years, rising from 236,000 in 2004 to 557,000 in 2014. Per 1,000 women over the age of 35, the number of such examinations rose from 70 in 2004 to 138 in 2014, almost doubling. These figures are far from ideal, but it is precisely the growth of such prophylactic examinations which became one of the factors of the mortality reduction from breast cancer [Axel 2012].

Mortality from malignant neoplasms of the female genital organs, despite a few swings, decreased slowly during the entire period. For 25 years, the death rate from cancer of the female genital organs, as well as from breast cancer, decreased by 1.4 times (Figure 11) in Moscow.

In most cases in Moscow, malignant neoplasms of the cervix uteri and corpus uteri are detected at their early stages. In 2014, $79 \%$ of the cases detected were diagnosed at stages I-II of the disease. But from 2004 to 2014 this proportion changed little (76\% in 2004). While malignant neoplasms of the cervix uteri are detected in the early stages (69\% in 2014 and 65\% in 2004), ovarian cancer is mainly detected only in stages III and IV (66\% in 2014 and 62\% in 2004, i.e. there was no growth in the proportion of early diagnoses), resulting in high mortality from cancer of this site. Check-ups and ultrasound examinations play an important role in the diagnosis of malignant neoplasms of female genital organs, but, according to experts, the proportion of patients with cervical cancer detected in this way is increasing very slowly [Axel 2009].

About a quarter of the deaths from malignant neoplasms of the female genital organs in Moscow are due to cervical cancer. Meanwhile, in contrast to other malignant neoplasms, cervical cancer mortality can be reduced to minimum levels. Most developed countries have recently begun using a vaccination against human papillomavirus (HPV) to prevent deaths from this cause. Several types of this virus are considered to be the cause (to provoke the development) of the absolute majority of cases of cervical cancer; in the absence of HPV, cervical cancer does not occur. Modern doctors consider it necessary to vaccinate all girls and young women, starting at age 12, who have not yet become sexually active. In many developed countries in Europe and North America, these vaccines have become mandatory for girls in recent years. In developed countries, such vaccines can also be given to boys [WHO 2015; WHO 2014].

In Russia too, such vaccinations can be given, but in most regions the procedure costs money. Moscow is one of just a few regions in which the vaccine (optional) can be given for free. Since the late 2000s, the vaccine "Vaccination (girls) against human papillomavirus" has been 
included in the annual regional calendar of preventive vaccinations ${ }^{5}$, and is recommended for girls aged 13 years. The results of this vaccination are not immediately noticeable, as most mortality from cervical cancer occurs at the age of 35 and over.

\section{Neoplasms of the digestive system}

Second place in the structure of mortality from cancer in Moscow, among both men and women, belongs to malignant neoplasms of the digestive system. This group of causes of death comprises two subgroups: malignant neoplasms of the stomach and malignant neoplasms of the intestines and anal canal. In 2014, these accounted for $25 \%$ of all deaths from cancer among men and $23 \%$ among women.

As in previous cases, mortality from malignant neoplasms of the digestive system in Moscow is better than in the other Russian megacity - St. Petersburg - but worse than in foreign megacities, particularly when it comes to mortality from cancer of the stomach (Table 7). In 2013, mortality from stomach cancer in Moscow surpassed that in foreign megacities by 3 times on average. Among the megacities here considered, especially noteworthy is London, where mortality from malignant neoplasms of these sites is very low. It is also low in Los Angeles. The difference in the level of mortality from malignant neoplasms of the intestine and anal canal is less, but still quite large. Most likely, this is due precisely to the fact that in these places there have long been established systems of prevention and screening of these diseases.

Table 7. Standardised death rates from cancer of the digestive system in 7 megacities, 1990, 2000, 2010, 2013, per 100,000

\begin{tabular}{|c|c|c|c|c|c|c|c|c|}
\hline \multirow{2}{*}{ Megacity } & \multicolumn{4}{|c|}{ Men } & \multicolumn{4}{|c|}{ Women } \\
\hline & $1990 *$ & 2000 & 2010 & $2013 * *$ & 1990* & 2000 & 2010 & $2013 * *$ \\
\hline \multicolumn{9}{|c|}{ Malignant neoplasms of the stomach $(\mathrm{C} 16)$} \\
\hline Berlin & 20.9 & 13.7 & 8.9 & 8.4 & 12.0 & 6.1 & 4.9 & 4.0 \\
\hline Hong Kong & 17.4 & 13.8 & 10.4 & 8.3 & 8.5 & 7.5 & 5.2 & 4.3 \\
\hline London & 11.9 & 6.9 & 4.4 & 4.0 & 3.1 & 2.4 & 1.8 & 1.6 \\
\hline Los Angeles & No data & 8.0 & 7.2 & 6.2 & No data & 4.4 & 3.7 & 3.5 \\
\hline Moscow & 63.3 & 44.1 & 26.0 & 22.2 & 30.0 & 20.7 & 13.0 & 11.4 \\
\hline St. Petersburg & 67.5 & 48.0 & 33.6 & 31.2 & 31.4 & 22.5 & 16.3 & 12.5 \\
\hline Singapore & 31.4 & 20.1 & 12.1 & 10.9 & 15.1 & 12.2 & 6.3 & 6.3 \\
\hline \multicolumn{9}{|c|}{ Malignant neoplasms of the intestine and anal canal (C17-C21) } \\
\hline Berlin & 28.0 & 26.8 & 18.3 & 20.7 & 21.9 & 17.0 & 14.4 & 11.6 \\
\hline Hong Kong & 25.4 & 26.4 & 25.2 & 24.0 & 16.7 & 18.0 & 15.4 & 15.3 \\
\hline London & 19.4 & 15.8 & 13.9 & 13.5 & 12.4 & 10.1 & 9.1 & 8.4 \\
\hline Los Angeles & 22.6 & 18.6 & 14.9 & 14.5 & 14.6 & 13.5 & 10.4 & 9.6 \\
\hline Moscow & 47.0 & 38.6 & 29.9 & 27.3 & 29.8 & 27.4 & 22.0 & 20.2 \\
\hline St. Petersburg & 48.1 & 46.2 & 37.3 & 34.6 & 32.4 & 33.1 & 24.1 & 24.7 \\
\hline Singapore & 26.0 & 30.6 & 26.6 & 23.6 & 23.7 & 24.4 & 15.9 & 17.7 \\
\hline
\end{tabular}

Notes: *Los Angeles 1995, ** Los Angeles 2012.

\footnotetext{
${ }^{5}$ Order of the Head of the Department of Health of Moscow from 16.01.2009 №9, "On the calendar of preventive vaccinations and the calendar of preventive vaccinations on epidemiological evidences". http://lawru.info/dok/2009/01/16/n765383.htm
} 
Trends in mortality from the groups of causes considered here show both similarities and differences. What they all have in common is a reduction in the indicators over the period under review. Where they differ is in the rates of decline of these indicators.

Of all the cancer sites examined, mortality from stomach cancer showed the greatest decline - 2.9 times for men and 2.7 times for women (Figure 11). The share of this site in the total number of deaths from all neoplasms in the last quarter of a century has decreased by $6 \%$ among men and $7.5 \%$ among women.

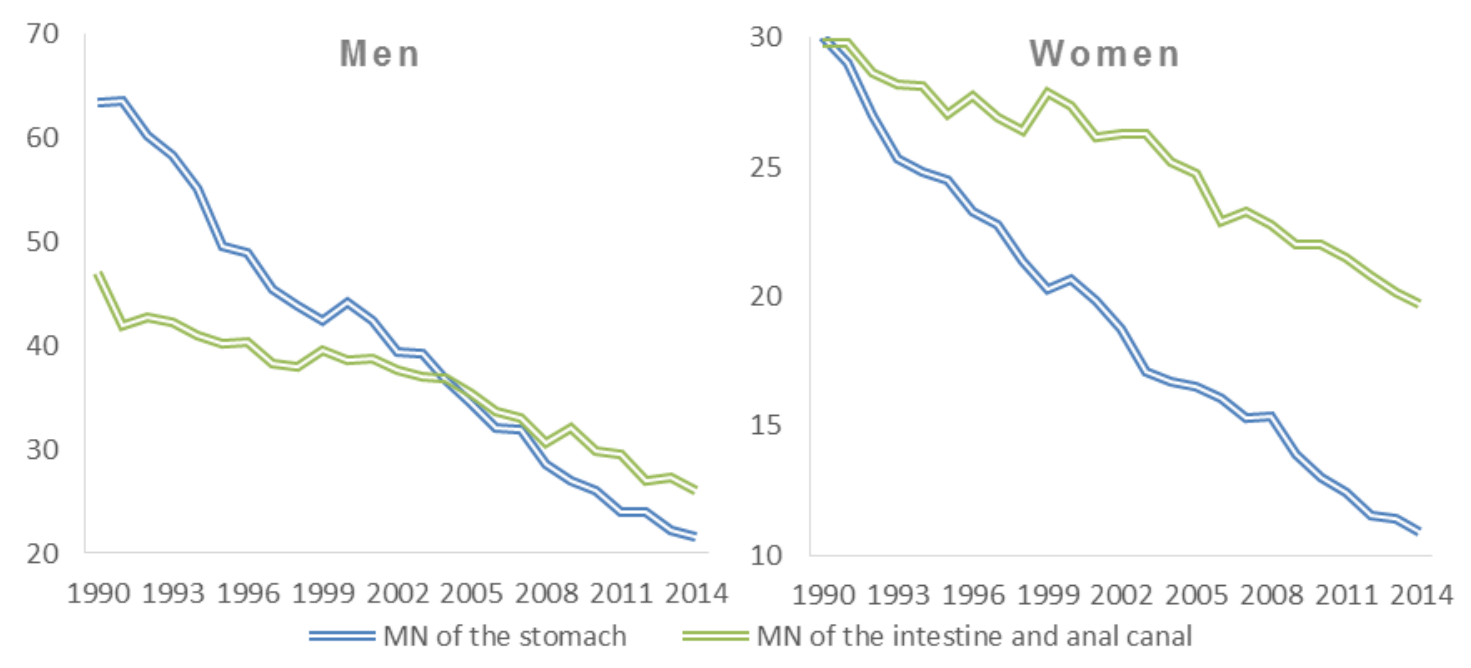

Figure 11. Standardised death rates from cancer of the digestive system in Moscow, 1990-2014, per 100,000

Stomach cancer has among the least favourable prognoses of any cancer site, and is characterised by the difficulty of early detection. The period between diagnosis and the moment of death is short: the median survival period of patients worldwide has for a long time remained at 7 months for both men and women (excluding posthumously diagnosed patients) and 5.7 months when taking into account posthumously diagnosed patients [Merabishvili 2013]. In Moscow, the proportion of cancer diagnoses made at stages III and IV increased from 55\% in 2004 to $63 \%$ in 2014.

According to experts, the magnitude of the incidence of stomach cancer is linked to diet. The presence in the diet of sufficient vegetables and animal and vegetable proteins significantly reduces the risk of gastric cancer. The most vivid example is the US, where the incidence of stomach cancer has declined several times over in the past 90 years of healthy diet campaigns [Merabishvili 2013].

For a long time it was believed that there were no effective programmes for stomach cancer screening, as there is no clearly defined specific factor for this disease. But starting in the late 1980s, the microorganism Helicobacter pylori (HP) came to be considered just such a factor. The presence of this organism in humans dramatically increases the likelihood of stomach cancer [Wroblewski 2010]. Unfortunately, tests for HP are not included in screening programmes and clinical examinations. 
One of the criteria for the quality control of cancer care is the indicator of reliability of statistics $^{6}$ [Kaprin et al. 2015: 11], which reflects, on the one hand, the level of recording of the disease, and on the other, progress in reducing mortality from specific sites. Since stomach cancer is characterised by a relatively short period between diagnosis and the moment of death, the reliability index also reflects the presence of the undercounting of patients with a given localisation (if the index is greater than 1). In Moscow (Table 8) in the last 10 years, this index has fluctuated around 1. In St. Petersburg, it is much less.

Table 8. Recording reliability index of malignant neoplasms of the stomach, 2004-2013

\begin{tabular}{l|c|c|c|c}
\hline \multirow{2}{*}{ Year } & \multicolumn{2}{|c|}{ Moscow } & \multicolumn{2}{c}{ St. Petersburg } \\
\cline { 2 - 5 } & Men & Women & Men & Women \\
\hline 2004 & 1.01 & 0.94 & 0.86 & 0.86 \\
2005 & 0.92 & 0.91 & 0.86 & 0.86 \\
2006 & 0.94 & 0.98 & 0.86 & 0.86 \\
2007 & 0.98 & 0.96 & 0.86 & 0.86 \\
2008 & 0.86 & 0.92 & 0.86 & 0.86 \\
2009 & 0.85 & 0.88 & 0.86 & 0.86 \\
2010 & 0.92 & 0.89 & 0.86 & 0.86 \\
2011 & 0.95 & 1.01 & 0.86 & 0.86 \\
2012 & 0.99 & 1.03 & 0.86 & 0.86 \\
2013 & 0.91 & 1.01 & 0.86 & 0.86 \\
\hline
\end{tabular}

Source: Authors' calculations on the data of the Ministry of Health.

Unlike mortality from stomach cancer, mortality from malignant neoplasms of the intestine and anal canal is characterised by a very slow decline (by 1.8 times in men and 1.5 in women; Figure 11). Whereas in 1990 mortality for men from stomach cancer was higher than that from neoplasms of the intestine and anal canal, by 2014 the localisations had been reversed: mortality from cancer of the intestine and anal canal had become higher than from cancer of the stomach.

\section{Prostate cancer}

In men, third place in the structure of mortality from neoplasms is occupied by prostate cancer (C61). The death rate from prostate cancer in Moscow and St. Petersburg throughout the whole period remained much higher than in the foreign cities considered, although the latter (except for London and Los Angeles) did show a tendency to increase some in the index (Table 9).

Trends in mortality from prostate cancer in Moscow are not like those from other locations: from the beginning of the 1990s and until 2006, the SDR grew, and then began a slow decline (Figure 12). As a result, by 2014 mortality from prostate cancer was higher than in 1990. Over the period from 2004 to 2014, the proportion of this cancer detected at stages III and IV decreased from $49 \%$ to $30 \%$.

\footnotetext{
${ }^{6}$ The number of patients who died within the first year after diagnosis from the previous year, to the number of patients in whom the tumor process was identified at stage IV after the diagnosis was made from the ones registered the previous year.
} 
Table 9. Standardised death rates from cancer of the prostate in 7 megacities, 1990, 2000, 2010, 2013, per 100,000

\begin{tabular}{l|c|r|r|r}
\hline Megacity & $1990^{*}$ & 2000 & 2010 & $2013^{* *}$ \\
\hline Berlin & 5.0 & 6.9 & 7.5 & 7.6 \\
Hong Kong & 5.0 & 6.9 & 7.5 & 7.6 \\
London & 3.3 & 3.2 & 2.9 & 2.7 \\
Los Angeles & No data & 20.0 & 17.1 & 14.1 \\
Moscow & 17.1 & 17.6 & 19.6 & 17.8 \\
St. Petersburg & 14.8 & 18.3 & 21.4 & 22.1 \\
Singapore & 8.0 & 11.4 & 8.7 & 11.3 \\
\hline
\end{tabular}

Notes: *Los Angeles 1995, **Los Angeles 2012.

Screening for prostate cancer, like for breast cancer, started in Moscow in 2002-2004, after the issuance of the Order of the Health Committee of Moscow №50 dated 06.02.2002, “On the implementation of the programme 'Targeted clinical examinations of the population of Moscow for 2002-2004' (Sub-programme 'Targeted clinical examinations of the male population for the detection of diseases of the prostate')". After that, all mass medical examination programmes came to include similar subprogrammes. Moscow's current targeted Programme, "Capital Health Care", includes the subprogramme "Targeted clinical examination of the male population for early detection of prostate disease". But, judging from the mortality rates, the effectiveness of these programmes is not very high.

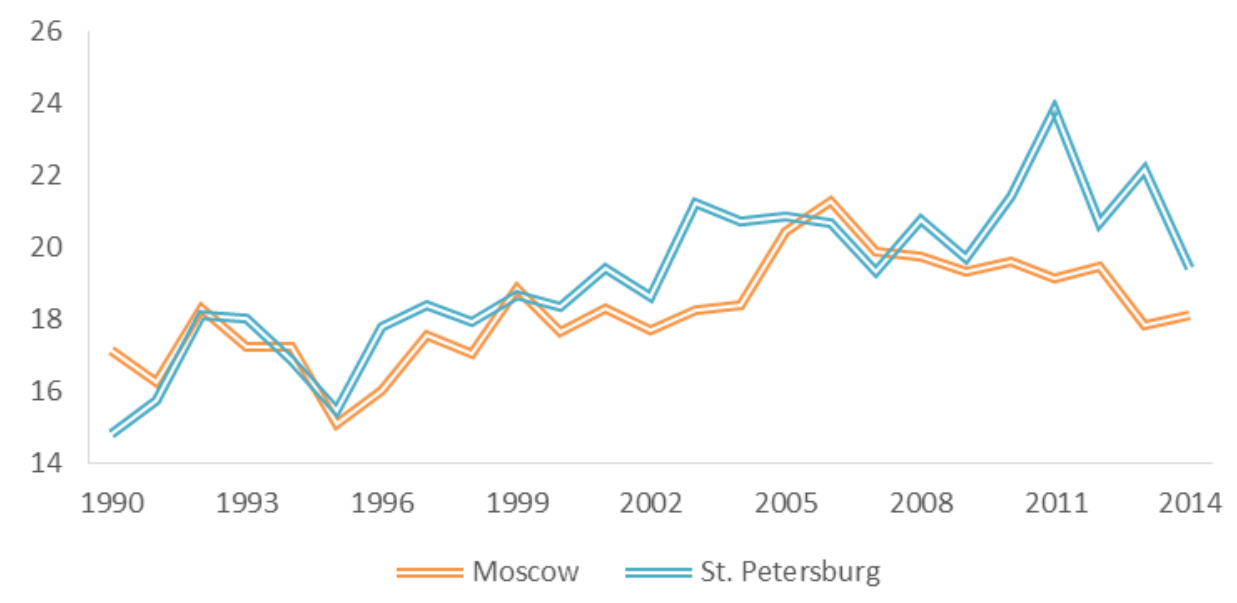

Figure 12. Standardised death rates from prostate cancer in Moscow and St. Petersburg, 1990-2014, per 100,000

In St. Petersburg, trends in mortality from prostate cancer until 2008 were very close to those in Moscow. The difference is in the growth of these indicators in the early 2010s. A number of experts explain such differences in the country's regional mortality by "the age structure and the degree of reporting reliability" [Merabishvili et al. 2014], although it is not clear how the age structure affects the standardised indicators.

\section{External causes of death}

External causes rank third in the mortality structure in Moscow. For a quarter century, the dynamics of the SDR from this class of causes were similar for men and women, despite a large difference in mortality. The growth of the SDR in the years 1990-1994 is mainly associated with 
the termination of the anti-alcohol campaign, but is also a direct result of the deep economic crisis affecting all post-Soviet countries [Shkolnikov et al. 2001, Andreev 2002].

The "spike" of 1998-2001 is most likely linked to Russia's transition to the 10th revision of the International Classification of Diseases (ICD-10), which was accompanied by the transfer of responsibility for coding causes of death from statistical offices to the physicians (in the case of external causes - forensic experts) establishing the cause of death. Officially, Russia switched to the ICD-10 in 1999, but Moscow really did so only in 2000 [Danilova 2015]. In general, during 1990-2014 mortality from external causes in Moscow declined 2.1 times for both men and women (Figure 13).

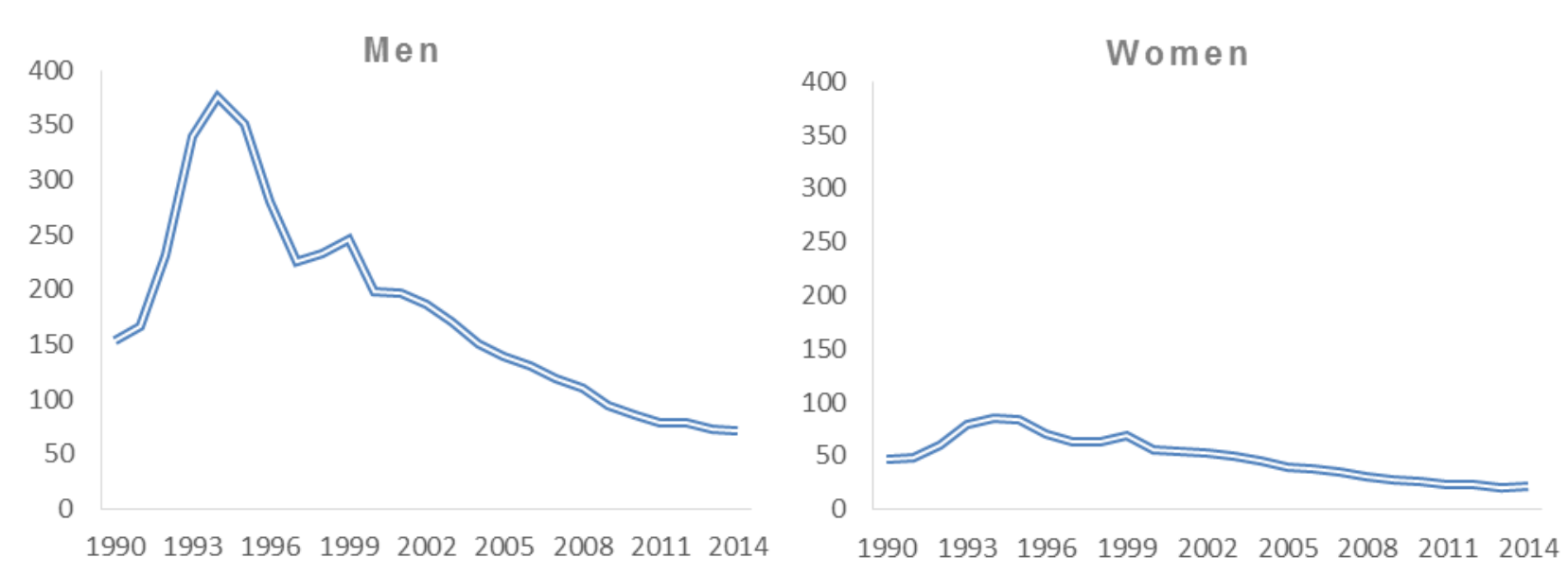

Figure 13. Standardised death rates from external causes of death in Moscow, 1990-2014, per 100,000

Nonetheless, the levels of mortality from external causes in both Moscow and St. Petersburg greatly surpassed and still surpass those in foreign megacities (Figure 14). In the year 2000, the SDR for men was 15 times higher - and in 2013, 8 times higher - than the minimum levels for these megacities, while for women the differences were 8 and 4 times, respectively.

The structure of mortality within the class of external causes of death in foreign megacities is very different from that in Moscow and St. Petersburg (Figure 15, Table 10). The main contribution to mortality from external causes in many of them, as in Moscow, comes from other external causes, but in general, pairwise comparisons reveal a rather mixed picture. 


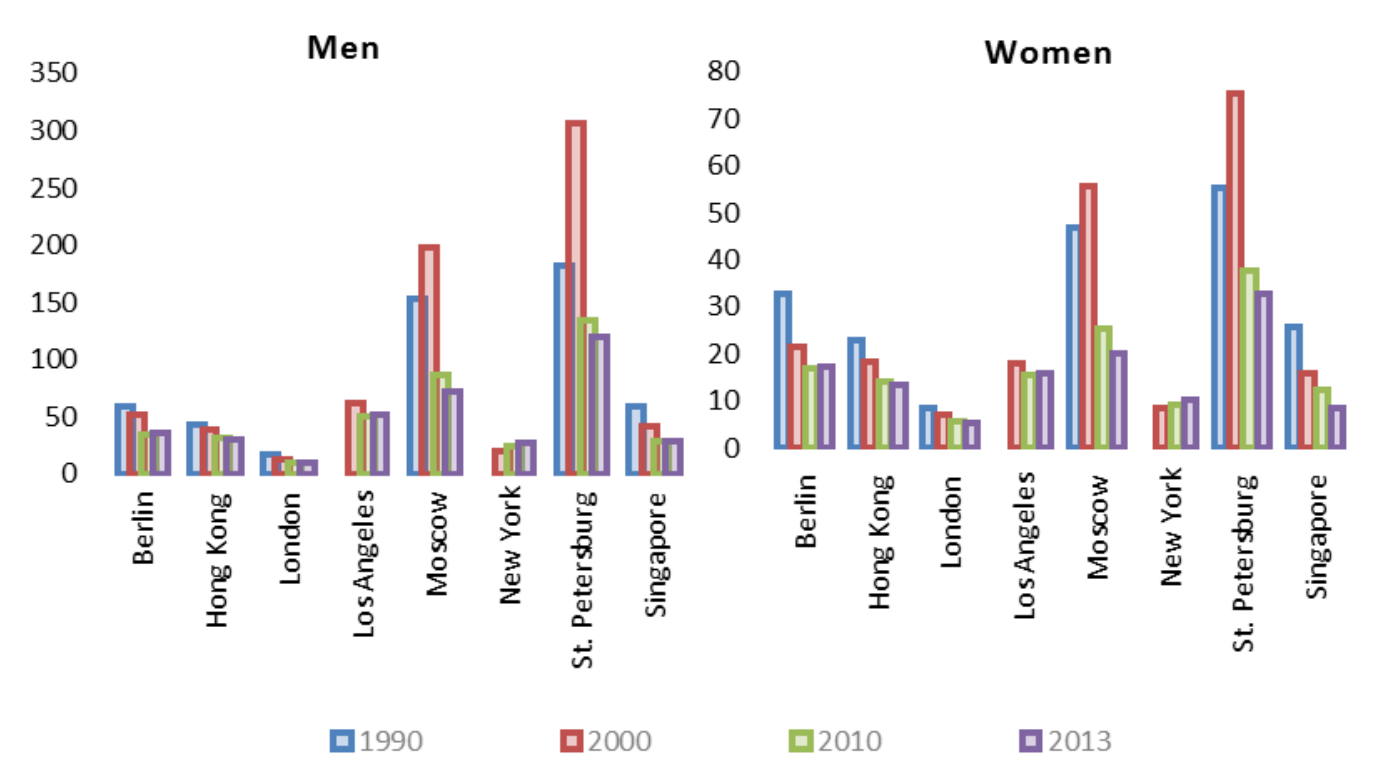

Figure 14. Standardised death rates from external causes of death in 8 megacities, 1990, 2000, 2010, 2013, per 100,000

Note: Los Angeles - 2012.

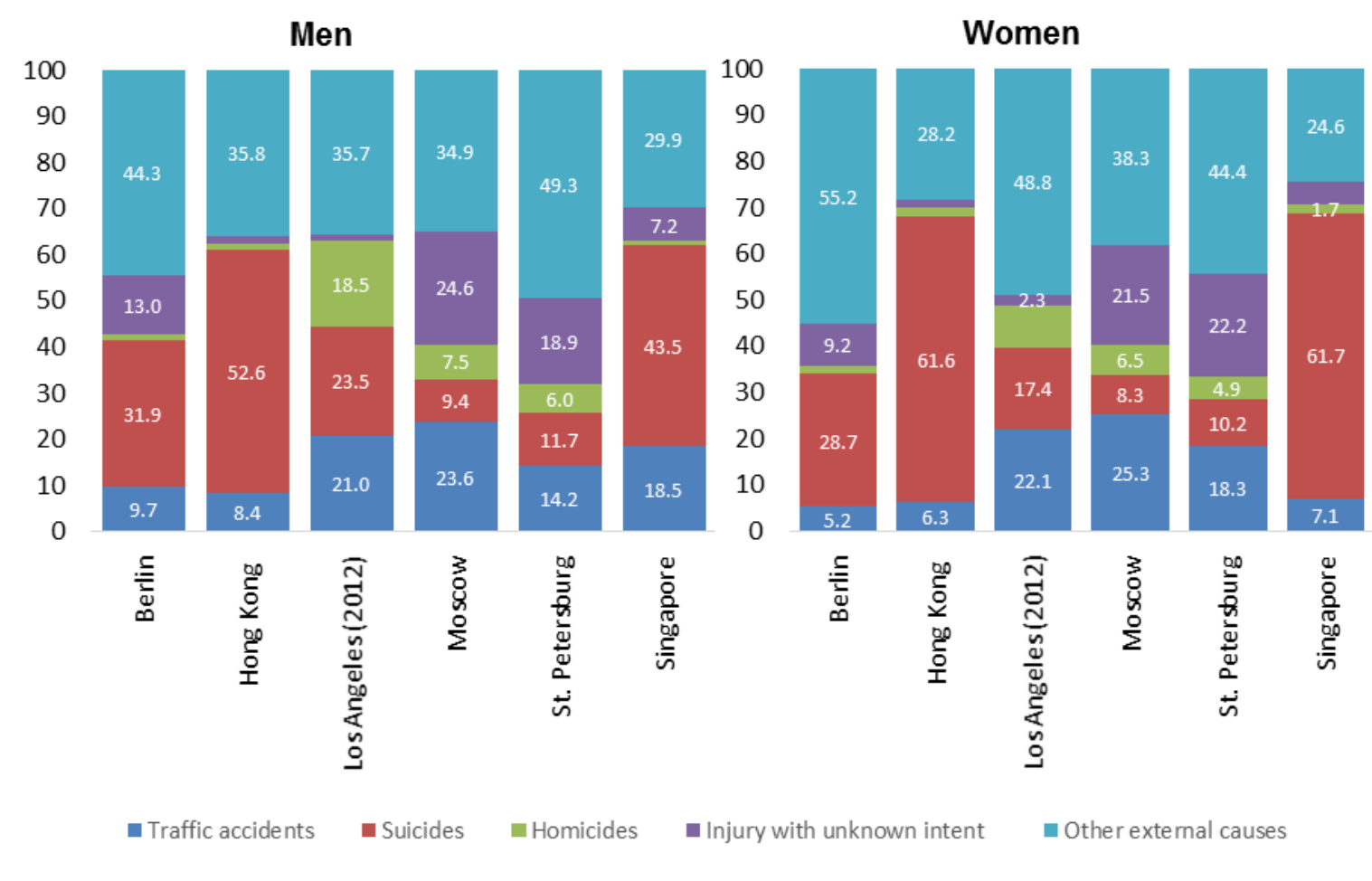

Figure 15. The structure of the standardised death rates of external causes of death in groups of causes in some megacities, 2013, \%

Moscow and St. Petersburg clearly surpass other megacities in mortality from road traffic accidents, but are far from the worst in terms of mortality from suicide and homicide. 


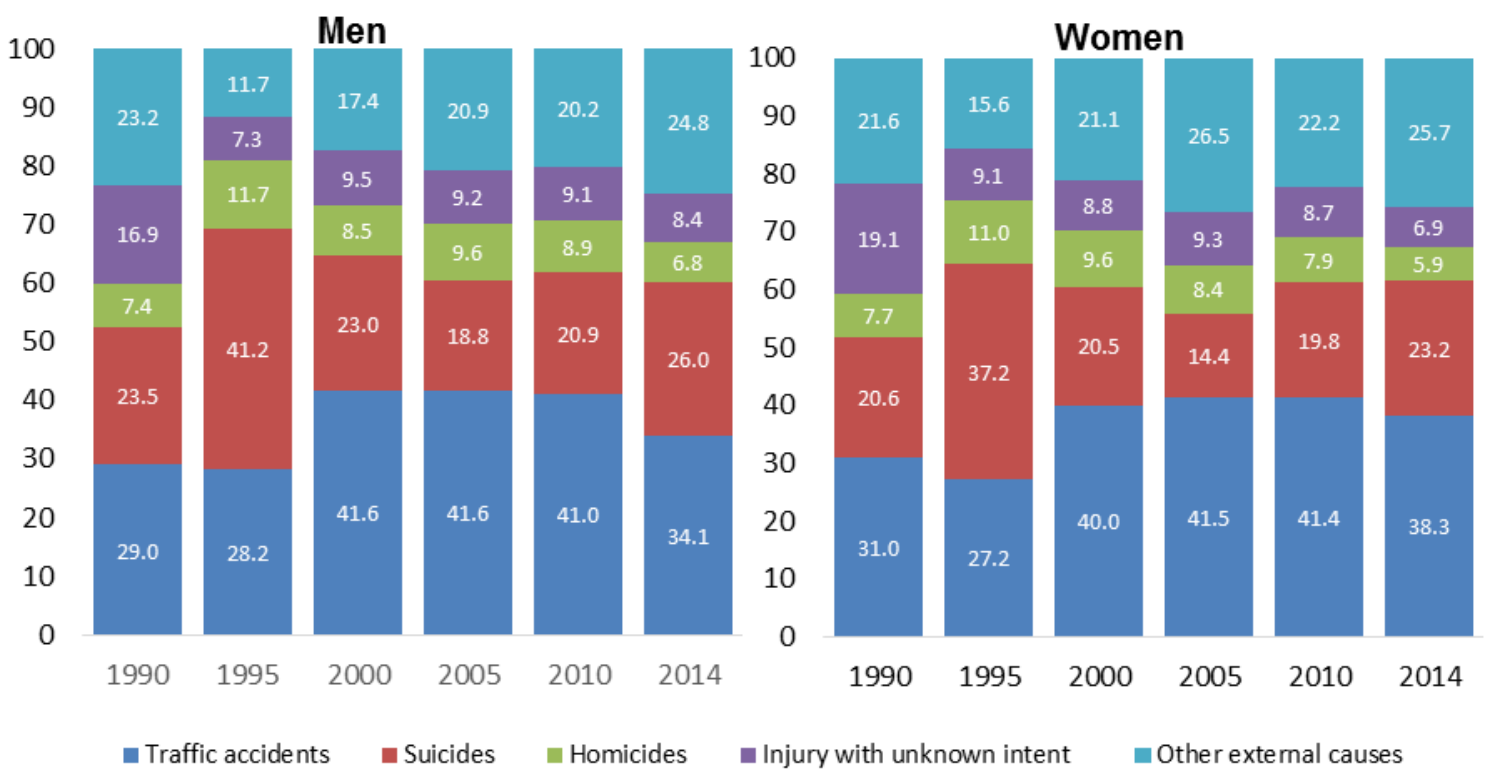

Figure 16. Structure of standardised death rates from external causes in Moscow, 1990-2014, \%

Table 10. Standardised death rates from road traffic accidents, homicides and suicides in 8 megacities, 1990, 2000, 2010, 2013, per 100,000

\begin{tabular}{|c|c|c|c|c|c|c|c|c|}
\hline \multirow[b]{2}{*}{ Megacity } & \multicolumn{4}{|c|}{ Men } & \multicolumn{4}{|c|}{ Women } \\
\hline & 1990* & 2000 & 2010 & $2013 * *$ & 1990* & 2000 & 2010 & $2013 * *$ \\
\hline \multicolumn{9}{|c|}{ Traffic accidents } \\
\hline Berlin & 13.7 & 7.1 & 2.7 & 3.5 & 5.2 & 3.0 & 2.2 & 0.9 \\
\hline Hong Kong & 9.1 & 3.9 & 2.9 & 2.6 & 5.1 & 1.9 & 0.9 & 0.8 \\
\hline London & 6.6 & 4.5 & 3.3 & 2.8 & 1.9 & 1.3 & 1.0 & 0.8 \\
\hline Los Angeles & 17.5 & 13.4 & 9.0 & 10.9 & 6.8 & 5.6 & 3.8 & 3.3 \\
\hline Moscow & 35.5 & 34.5 & 17.3 & 17.0 & 10.1 & 11.7 & 5.7 & 5.1 \\
\hline New York & 10.1 & 6.8 & 4.8 & 5.1 & 4.3 & 3.2 & 1.9 & 2.0 \\
\hline St. Petersburg & 33.7 & 38.5 & 16.9 & 17.0 & 10.9 & 13.4 & 6.4 & 6.0 \\
\hline Singapore & \multicolumn{7}{|c|}{ Suicides } & 0.6 \\
\hline Berlin & 20.4 & 18.5 & 13.6 & 11.5 & 9.9 & 6.7 & 4.6 & 5.0 \\
\hline Hong Kong & 15.0 & 16.1 & 16.5 & 15.9 & 10.8 & 10.0 & 8.4 & 8.3 \\
\hline London & 6.0 & 4.2 & 2.9 & 2.5 & 4.2 & 2.8 & 1.8 & 1.5 \\
\hline Los Angeles & 18.6 & 12.7 & 12.5 & 11.9 & 3.8 & 3.0 & 2.9 & 2.1 \\
\hline Moscow & 25.8 & 18.7 & 7.8 & 6.7 & 8.9 & 4.9 & 2.2 & 1.7 \\
\hline New York & 10.5 & 8.6 & 8.7 & 8.9 & 3.5 & 2.2 & 2.6 & 3.0 \\
\hline St. Petersburg & 30.8 & 29.0 & 16.6 & 14.0 & 8.5 & 7.0 & 3.7 & 3.3 \\
\hline Singapore & 17.8 & 13.7 & 10.4 & 12.5 & 12.6 & 6.6 & 4.9 & 5.2 \\
\hline Tokyo & 17.4 & 28.1 & 25.5 & 22.6 & 9.8 & 11.4 & 11.4 & 11.1 \\
\hline \multicolumn{9}{|c|}{ Homicides } \\
\hline Berlin & 1.9 & 1.1 & 0.4 & 0.4 & 1.5 & 0.8 & 0.4 & 0.3 \\
\hline Hong Kong & 2.6 & 0.9 & 0.5 & 0.5 & 1.3 & 0.9 & 0.6 & 0.3 \\
\hline Los Angeles & 18.2 & 16.5 & 9.9 & 9.7 & 4.9 & 2.9 & 1.9 & 1.4 \\
\hline Moscow & 11.3 & 16.9 & 7.6 & 5.4 & 3.6 & 5.3 & 2.0 & 1.3 \\
\hline New York & 17.3 & 14.5 & 10.5 & 6.5 & 3.4 & 2.7 & 2.0 & 1.3 \\
\hline St. Petersburg & 12.2 & 29.3 & 11.1 & 7.1 & 4.2 & 9.0 & 3.3 & 1.6 \\
\hline Singapore & 1.7 & 1.6 & 0.6 & 0.3 & 1.1 & 0.6 & 0.1 & 0.1 \\
\hline
\end{tabular}

Notes: *Los Angeles 1995, New York 1997: **Los Angeles 2012. 
The structure of mortality from external causes has changed over time in Moscow. But the essential has remained constant: the main contribution is made by two groups of causes, "Events of undetermined intent" (EUI) and the residual group of causes "other external causes" (Figure 16).

In third place in Moscow are transport accidents, accounting in 2014 for $24.8 \%$ of mortality from external causes among men and $25.7 \%$ among women. The bulk of the deaths due to transport accidents in Moscow and other megacities is associated with road accidents. Over 25 years, mortality from transport accidents has decreased by a factor of 2 for men and 1.8 for women (Figure 17). This decrease occurred in waves. The first wave ended with a minimum in 1998, followed by a new rise and a new fall. In 2007, the 1998 level was reached, after which the decline continued until the early 2010s, when the indicators stabilised. Trends in mortality from road accidents in Moscow differ little from those nationwide [Fattakhov 2015].

Despite the reduction, the mortality rate from transport accidents in Moscow and St. Petersburg is much higher than in foreign megacities (Table 9), where mortality from this cause is decreasing much faster than in the two Russian cities. As a result the gap between Moscow and St. Petersburg and other megacities considered here has grown over the last quarter century.

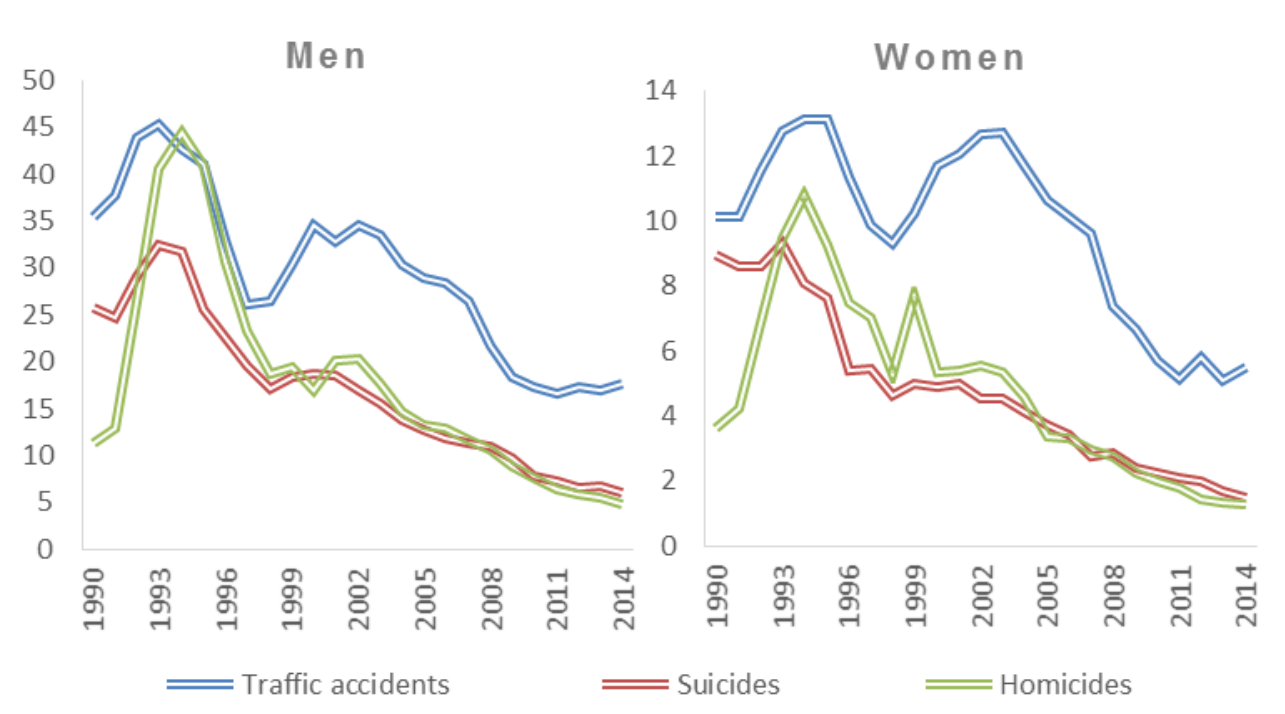

Figure 17. Standardised death rates from road traffic accidents, homicide and suicide in Moscow, 1990-2014, per 100,000

In Russia as a whole and in many regions, programmes are being set up to reduce mortality from a number of causes. A large part of these programmes is aimed at reducing mortality from traffic accidents. So, to implement the measures of the first phase of the Conception of Demographic Policy of the Russian Federation for the period up to 2025 (2007-2010), by order №170-r of the Russian Government of February 14, 2008, an action plan was approved for 20082010 , including a set of measures for the prevention, diagnosis and treatment of cardiovascular disease, as well as for ensuring the provision of timely and high-quality medical care for victims of traffic accidents. In recent years, the rules of road safety have changed somewhat. At the end of 2013, D.A. Medvedev signed the Russian Federation Government Resolution №864 dated October 
3, "On the federal target programme 'Improving traffic safety in $2013-2020$ ", , which is included in the list of priority federal programmes for 2015.

This programme, it is declared, will by the year 2020 result in " 8,000 fewer deaths $(28.82 \%)$, including children, due to road accidents than in $2012 \% 8$. But, judging by the dynamics of mortality from traffic accidents, in Moscow these programmes have not been achieving visible results in recent years.

The next most important cause of death contributing to overall external mortality is suicide. In Moscow, the share of this cause in 2014 accounted for $8.4 \%$ of all deaths from external causes of death for men and 6.9\% for women. Over 25 years, the SDR from suicide in Moscow decreased by 4.3 times among men and by 6.1 times among women. The decline began after the rise of the SDR in the early 1990s and went on evenly until the end of the period. Perhaps this is the highest rate of decline over the years considered. However, according to experts, the number of deaths due to suicide in Russia is underestimated. Some of these deaths are categorised as other causes, but more often are attributed to events of undetermined intent; it is estimated that some $20 \%$ of all suicides in Russia are put into this group [Andreev et al. 2015]. Analysis of the death certificates of working-age Moscow men and women who died from injuries and poisoning also showed that Moscow is no exception [Semenov, Antonova 2007]. However, this phenomenon is not only a Russian problem, but a worldwide one [Vasin 2015].

It may be due precisely to significant underreporting that mortality from suicide in Moscow and St. Petersburg is often lower than in foreign megacities; in contrast, the proportion of deaths and the standardised death rate from causes of unknown intent are also significantly higher in Moscow (Figures 15 and 16, Table 9).

Unfortunately, unlike for road accidents, Russia has no programmes aimed at reducing mortality from suicide. Moscow's prospects from this point of view look better. According to the State Programme of the City of Moscow for 2012-2016, "Health care development in the city of Moscow (Capital Health Care)", by the end of 2016 suicidological consulting rooms are to be opened in outpatient clinics and mental clinics.

Like the number of suicides, the number of deaths resulting from homicide is also underreported. Some homicides are likely to be classified as accidents, but more often they are coded as events of undetermined intents. It is estimated that these account for approximately 35$40 \%$ of all homicides in Russia [Andreev et al. 2015].

According to official figures, between 1990 and 2014 mortality from homicide in Moscow, having ended its period of expansion, decreased 2.3 times in men and 2.8 times in women (Figure 18). After the spike in mortality from homicide in the early 1990s, further decline was almost linear. Mortality from homicide in Moscow is lower than in Los Angeles and New York, but significantly higher than in all the other foreign megacities. In the EU-15, the level of mortality as a result of homicide is almost 9 times higher for men and 5.5 times lower for women than in Moscow.

\footnotetext{
${ }^{7}$ http://www.rg.ru/2013/10/08/bezopas-site-dok.html

${ }^{8}$ http://fcp.economy.gov.ru/cgi-bin/cis/fcp.cgi/Fcp/ViewFcp/View/2015/409/
} 
Almost a quarter of male deaths due to external causes and more than $21 \%$ of female deaths are classified as injuries with unknown intent. According to the principles of ICD-10, this group includes cases where the available information is insufficient for experts to conclude whether the event happened as the result of an accident, self-harm or violence. The main difficulty is to correctly assess the available information. An analysis by S.A. Vasin of publications on the subject showed that, for various reasons, in all developed countries there are cases where the available data are sufficient to classify them as suicides or accidents, yet which are nonetheless classified as EUI [Vasin 2015: 91-92]. In Russia, where mortality from homicide is already high, homicides too are classified as EUI [Ivanova et al. 2013].

The proportion of deaths from EUI in Moscow is significantly higher than in all foreign megacities, and the SDR for all deaths classified as EUI is about three times higher. Comparison with the EU-15 countries showed that the SDR for all deaths classified as EUI in Moscow is 9 times higher for men and 6 times for women. This may be linked to the fact that the data for mortality in Moscow include virtually no repeated medical certificates of death "instead of a preliminary one" and "instead of a final one" which are meant just to clarify the initially established cause of death.

In Moscow, the SDR for EUI grew significantly in the early 1990s, and then in the mid1990s began its slow and inconsistent decline. In the early 2000s, along with the transition to the ICD-10 and the handing over of coding the cause of death to the doctors establishing the cause of death, the proportion of EUI in Russian mortality fell sharply, but the proportion of deaths of unknown cause also suddenly and inexplicably increased [Ivanova et al. 2013]. S.A. Vasin has shown that if we sum up EUI and all unknown causes of death except for the cause "old age", it turns out that mortality from this group in Moscow hardly reacted at all to the transition to the ICD-10 [Vasin 2015: 103-104].

We conducted a similar calculation for Moscow, taking the EUI and the entire ICD class of "Symptoms, signs, abnormal clinical and laboratory findings, not elsewhere classified" (hereafter: ill-defined causes; Figure 18). The sum of EUI and ill-defined causes in men shows no tendency at all to decrease from 2000 to 2008, but afterward it decreases slightly; in addition, the number of deaths from just ill-defined causes again begins to grow after 2008.

The group called "other external causes of death" consists essentially of non-transport accidents. The estimated number of deaths from non-transport accidents in Russia is underreported by $15-20 \%$ as a result of their being classified as EUI [Andreev et al. 2015].

Mortality from other external causes in Moscow is more than 2 times lower for men, and 1.6 times lower for women, than in St. Petersburg. For women, this level is about the same as in foreign megacities, while for men it is 1.4-3 times higher. But in its contribution to overall mortality from external causes, Moscow does not stand out from other cities for either men or women (Figure 15 and 16). 


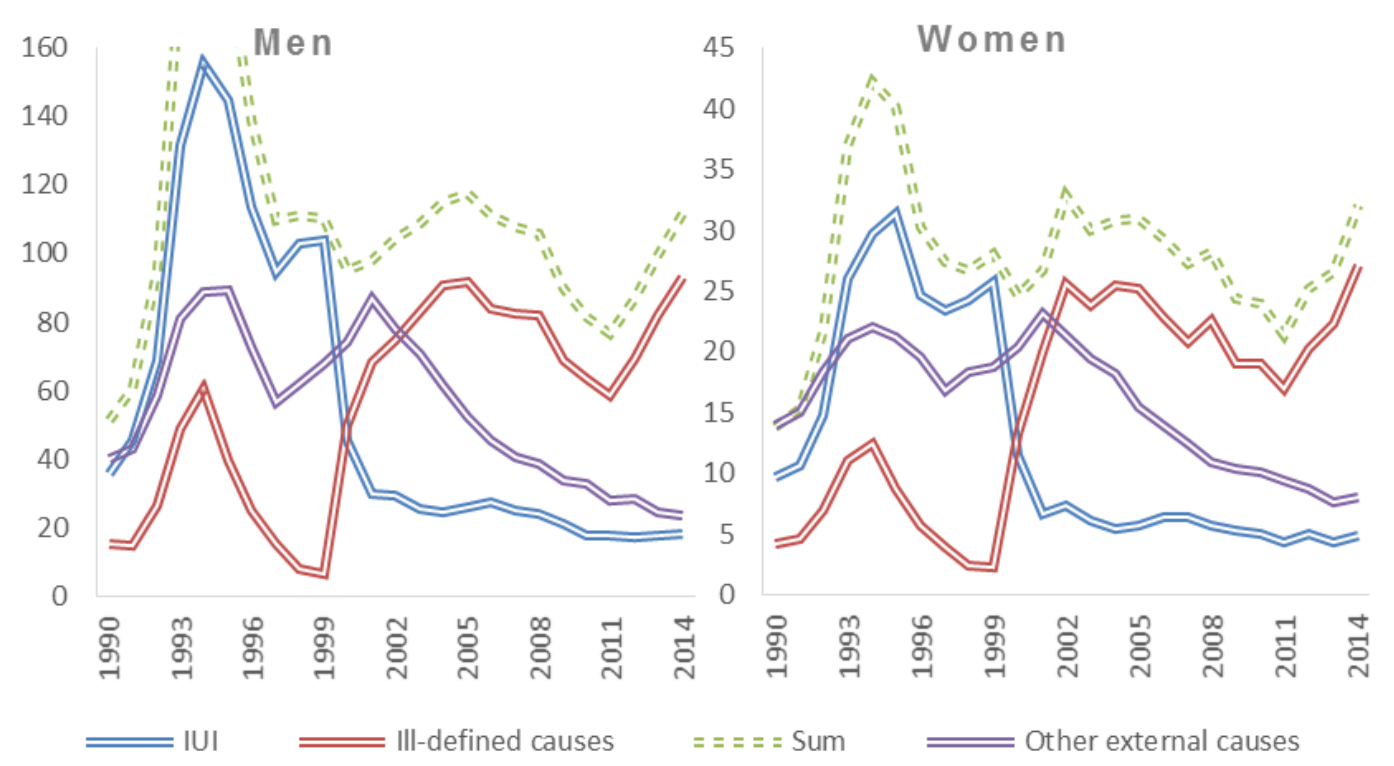

Figure 18. Standardised death rates from injury with uncertain intent, ill-defined causes and "other external causes" in Moscow, 1990-2014, per 100,000

Note: EUI - Injury of unknown intent.

After 2000, among other external causes in both Moscow and foreign megacities, the most common have been accidental falls - a fairly noticeable cause in the structure of causes of death among elderly persons.

In Moscow, such an important cause of death as accidental alcohol poisoning goes practically unregistered [Andreev 2016], a fact which undoubtedly distorts the real structure of mortality from external causes.

\section{Diseases of the respiratory system}

Diseases of the respiratory system occupy fourth place in the structure of causes of death in Moscow (Figure 24), whereas in foreign megacities these causes are in third place.

The standardised death rates from respiratory diseases in Moscow and St. Petersburg have been and remain below those in other megacities (Figure 19); this in itself is not an advantage, because in Russia the average age of death from this cause is fairly low, whereas in developed countries it is often higher than from diseases of the circulatory system. 


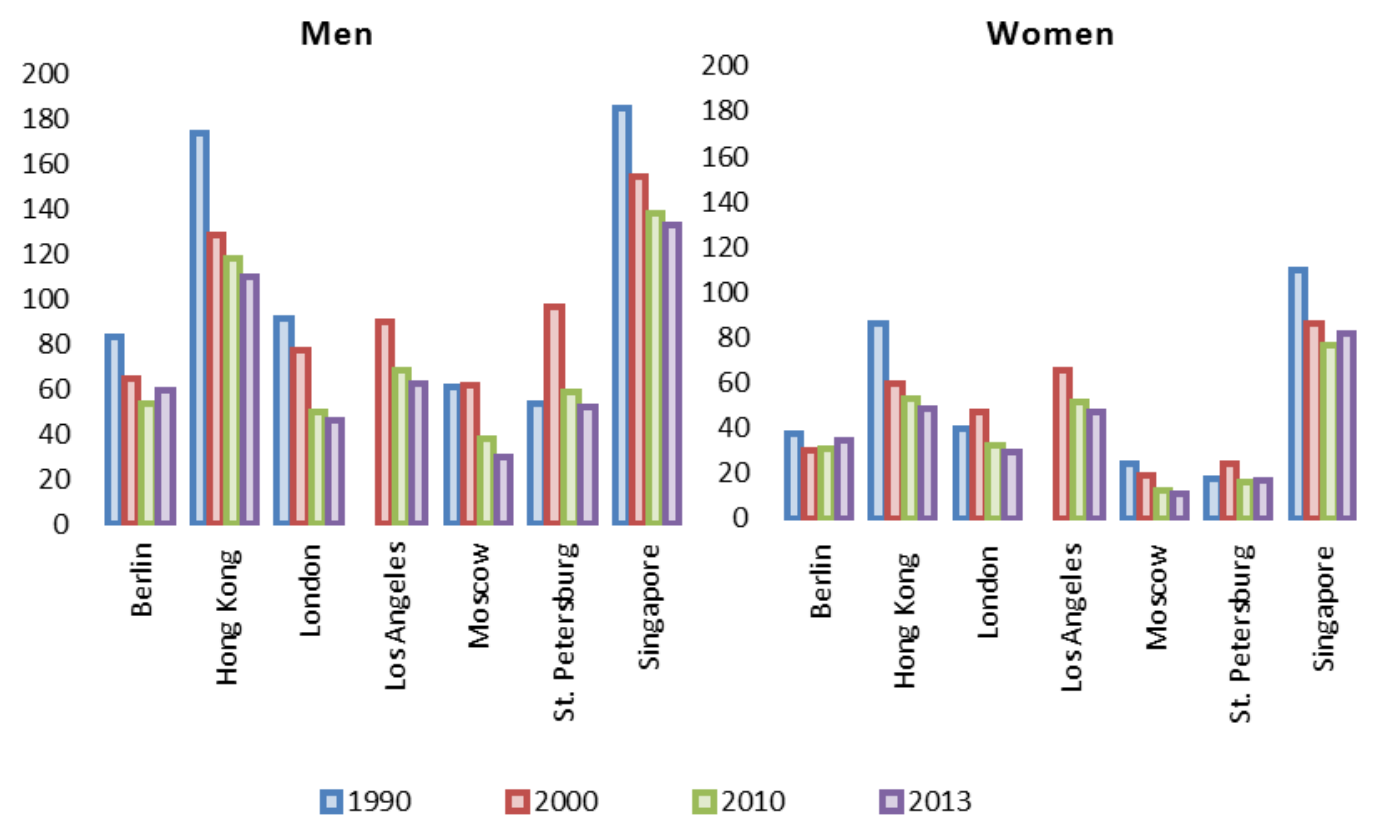

Figure 19. Standardised death rates from respiratory diseases in 7 megacities, 1990, 2000, 2010, 2013, per 100,000

Note: Los Angeles - 2012.

The main contribution to mortality from respiratory diseases until the mid-2000s came from deaths from pneumonia and bronchitis. After 2005, Moscow succeeded in reducing mortality from bronchitis to a minimum, but pneumonia now accounts for almost $60 \%$ of all deaths from respiratory diseases. From 1990 to 2014, the SDR from respiratory diseases in Moscow decreased 2.1 times among men and 2.5 times among women (Figure 20). In its dynamics, the same periods stand out as in the dynamics of the SDR from diseases of the circulatory system and most external causes: a rise in the early 1990s, a peak in 1994, a reduction and trough in 1998, a new rise and after 2003 - a steady decline. The only variation is in the last maximum point: 2001 for men and 2002 for women.

Deaths from pneumonia in all megacities examined constitute no less than $35 \%$ of all deaths from respiratory diseases. In Singapore, the proportion of pneumonia was $74 \%$ among men and $91 \%$ among women, and deaths from respiratory diseases account for more than $20 \%$ of all deaths. New York statistics do not include data for the whole class of diseases of the respiratory system, only data on pneumonia and chronic obstructive pulmonary disease. Compared to these megacities, the mortality rate from pneumonia in Moscow is the lowest (Table 11), but one must take into account that, in developed countries, those who die from pneumonia are mostly elderly people (very elderly, one might say), who almost always suffer from more than one disease at the time of death. What cause will be listed on the death certificate as the main one and thus fall into the statistics depends on the rules for selecting the underlying cause of death in that particular country and region. 


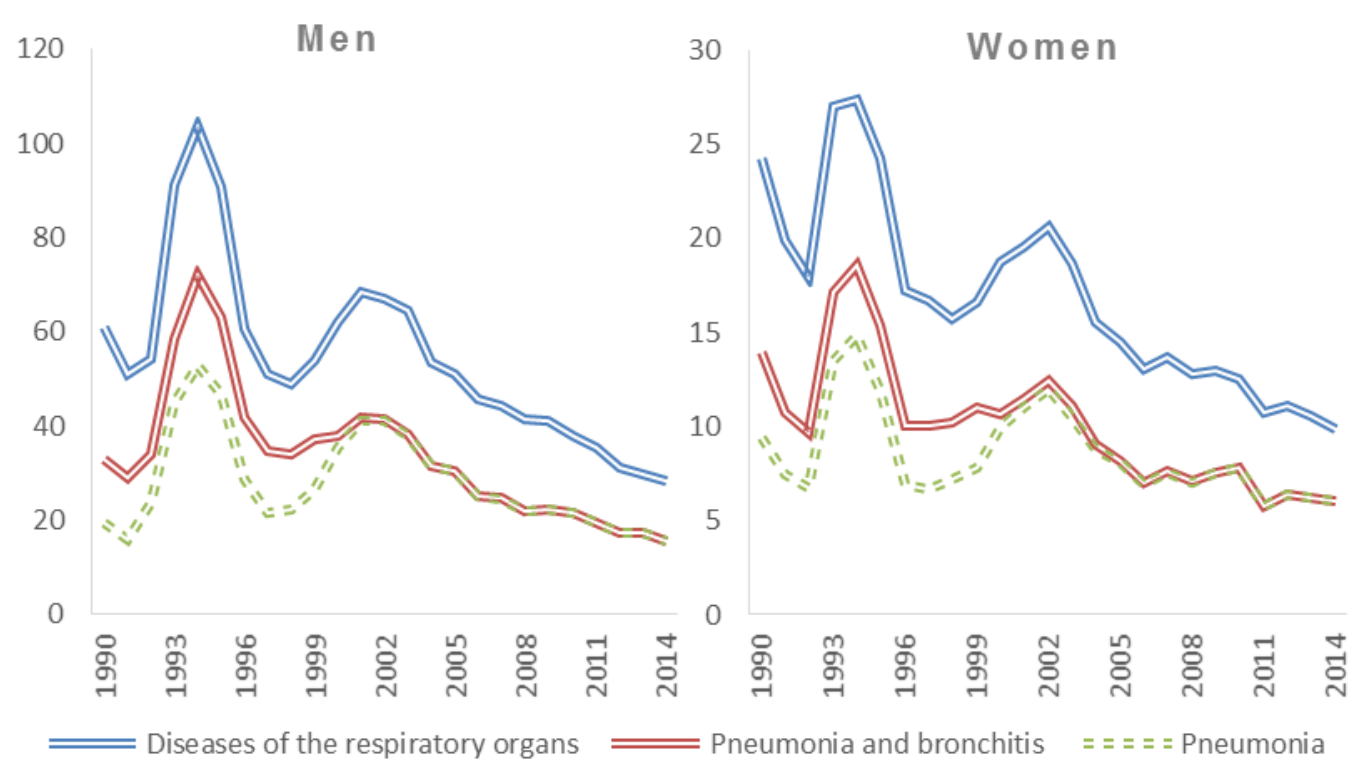

Figure 20. Standardised death rates from respiratory diseases in Moscow, 1990-2014, per 100,000

Table 11. Standardised death rates from pneumonia in 8 metropolitan areas, 1990, 2000, 2010, 2013, per 100,000

\begin{tabular}{l|c|c|c|c|c|c|c|c}
\hline \multirow{2}{*}{ Megacity } & \multicolumn{4}{|c}{ Men } & \multicolumn{4}{c}{ Women } \\
\cline { 2 - 9 } & $1990^{*}$ & 2000 & 2010 & $2013^{* *}$ & $1990^{*}$ & 2000 & 2010 & $2013^{* *}$ \\
\hline Berlin & 24.8 & 22.2 & 20.8 & 20.6 & 13.8 & 10.4 & 10.7 & 11.3 \\
Hong Kong & 69.6 & 63.4 & 73.3 & 75.3 & 36.5 & 37.5 & 39.3 & 38.7 \\
Los Angeles & No data & 39.1 & 27.8 & 26.9 & No data & 33.6 & 22.9 & 21.2 \\
Moscow & 19.5 & 35.4 & 21.5 & 17.2 & 9.4 & 10.0 & 7.8 & 6.2 \\
New York & 35.8 & 29.6 & 28.9 & 28.4 & 23.8 & 19.8 & 19.8 & 17.7 \\
St. Petersburg & 16.8 & 59.3 & 34.2 & 31.4 & 6.9 & 14.7 & 9.4 & 10.6 \\
Singapore & 92.9 & 102.2 & 106.2 & 111.0 & 72.9 & 68.6 & 66.2 & 73.8 \\
Tokyo*** & 84.6 & 58.0 & 46.8 & 43.8 & 40.4 & 28.7 & 22.1 & 19.9 \\
\hline
\end{tabular}

Notes:*New York 1997; **Los Angeles 2012; ***pneumonia and bronchitis.

\section{Digestive system diseases}

In Moscow in 2014, 4.3\% of all male deaths and 4.2\% of all female deaths resulted from digestive diseases. Over 25 years, the contribution of this class of causes of death to the SDR increased by 1 percentage point for men and 1.3 percentage points for women. The death rate from diseases of the digestive system from 1990 to 2014 decreased by 1.3 times among men and 1.2 times among women, and the actual decrease in the mortality rate from this class only began in 2008 (Figure 21). In St. Petersburg, the share of this class is no different from that of Moscow, and the mortality rate is slightly higher. In Berlin, the death rate from diseases of the digestive system is a little lower than in Russian cities. In other megacities, 2-4 times fewer people die from this class of causes of death (Table 12). 


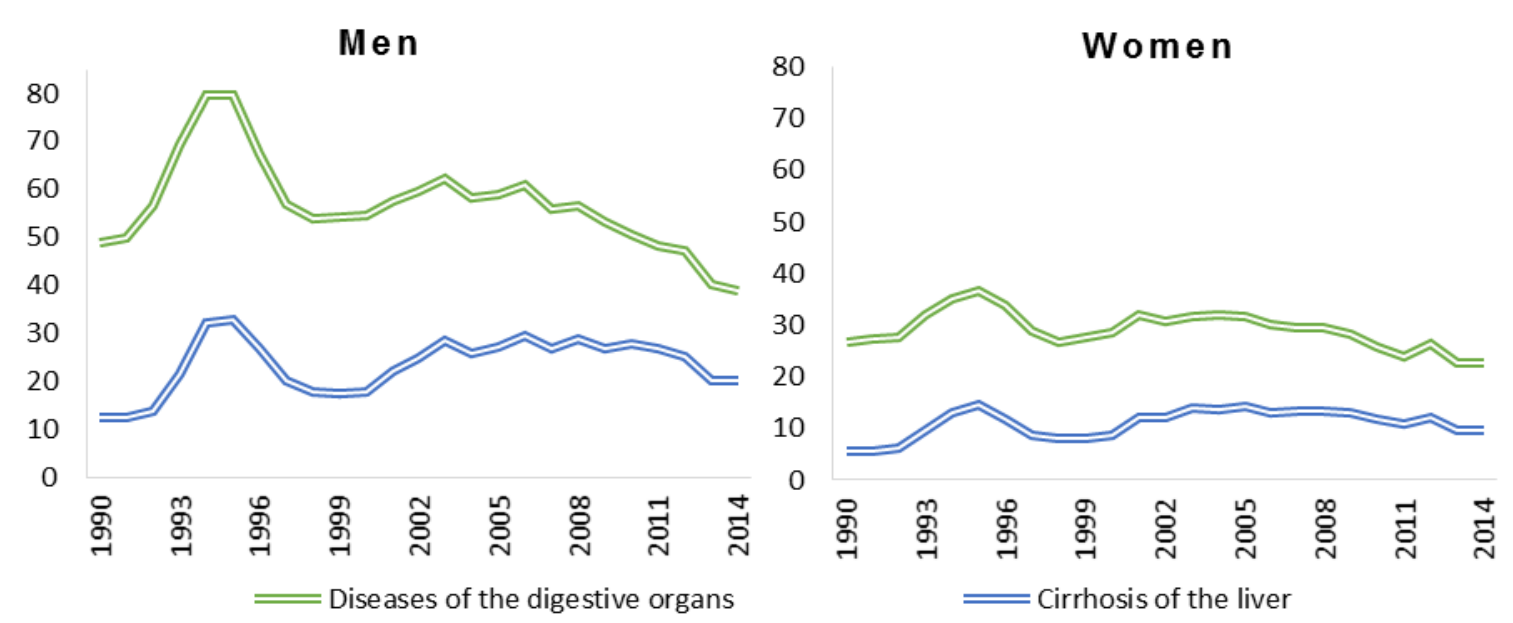

Figure 21. Standardised death rates from diseases of the digestive system and cirrhosis of the liver in Moscow, 1990-2014, per 100,000

The main contribution to mortality from digestive diseases comes from cirrhosis of the liver, whose mortality dynamics also determined the dynamics of the whole class. During the period from 1990 to 2014, the SDR from cirrhosis of the liver in Moscow grew by 40\% among both men and women. Due to this, the contribution of cirrhosis increased from $26 \%$ to $52 \%$ for men and from $21 \%$ to $43 \%$ for women over 25 years. Mortality from cirrhosis of the liver in Moscow and St. Petersburg is several times higher than in foreign cities.

Table 12. Standardised death rates from diseases of the digestive system and cirrhosis of the liver in 7 megacities, 1990, 2000, 2010, 2013, per 100,000

\begin{tabular}{|c|c|c|c|c|c|c|c|c|}
\hline \multirow{2}{*}{ Megacity } & \multicolumn{4}{|c|}{ Men } & \multicolumn{4}{|c|}{ Women } \\
\hline & $1990^{*}$ & 2000 & 2010 & $2013 * *$ & 1990* & 2000 & 2010 & $2013 * *$ \\
\hline \multicolumn{9}{|c|}{ Diseases of the digestive system } \\
\hline Berlin & 59.6 & 47.0 & 36.7 & 36.8 & 36.4 & 28.0 & 25.1 & 20.3 \\
\hline Hong Kong & 36.3 & 28.5 & 20.9 & 16.6 & 20.6 & 17.5 & 10.9 & 9.3 \\
\hline London & 9.4 & 13.5 & 12.6 & 10.4 & 4.9 & 5.9 & 5.3 & 4.6 \\
\hline Los Angeles & No data & 31.9 & 25.4 & 26.6 & No data & 18.4 & 14.1 & 14.1 \\
\hline Moscow & 48.8 & 54.7 & 50.6 & 40.3 & 26.7 & 28.5 & 25.7 & 22.8 \\
\hline St. Petersburg & 46.6 & 59.5 & 61.3 & 48.7 & 27.1 & 31.8 & 30.7 & 25.3 \\
\hline Singapore & 30.5 & 15.0 & 13.4 & 11.4 & 14.9 & 10.6 & 9.9 & 8.2 \\
\hline \multicolumn{9}{|c|}{ Cirrhosis of the liver } \\
\hline Hong Kong & 10.3 & 10.5 & 4.4 & 3.4 & 4.2 & 5.0 & 2.1 & 1.5 \\
\hline London & 8.8 & 13.0 & 12.1 & 10.1 & 4.8 & 5.8 & 5.2 & 4.5 \\
\hline Los Angeles & No data & 4.7 & 2.7 & 3.3 & No data & 3.6 & 3.2 & 3.8 \\
\hline Moscow & 12.5 & 17.8 & 27.8 & 20.1 & 5.5 & 8.6 & 11.9 & 9.5 \\
\hline New York & 17.3 & 12.0 & 9.1 & 9.4 & 5.1 & 3.6 & 3.4 & 3.5 \\
\hline St. Petersburg & 11.7 & 15.4 & 27.4 & 21.6 & 4.8 & 8.9 & 12.7 & 9.6 \\
\hline Singapore & 11.6 & 5.3 & 4.3 & 3.0 & 3.5 & 2.8 & 2.4 & 2.2 \\
\hline
\end{tabular}

Notes: *New York 1997; **Los Angeles 2012.

\section{Certain infectious and parasitic diseases}

The contribution of infectious and parasitic diseases to the standardised death rate from all causes in Moscow in 2014 was $1.7 \%$ for men and 1.1\% for women. In 1990, these shares were even smaller $-1.1 \%$ and $0.5 \%$, respectively. Since 1990, the SDR from infectious and parasitic diseases among men has barely changed, but among women it has grown, a growth which (albeit at a slow pace and in spurts) has continued since the beginning of the 2000s (Figure 22). 


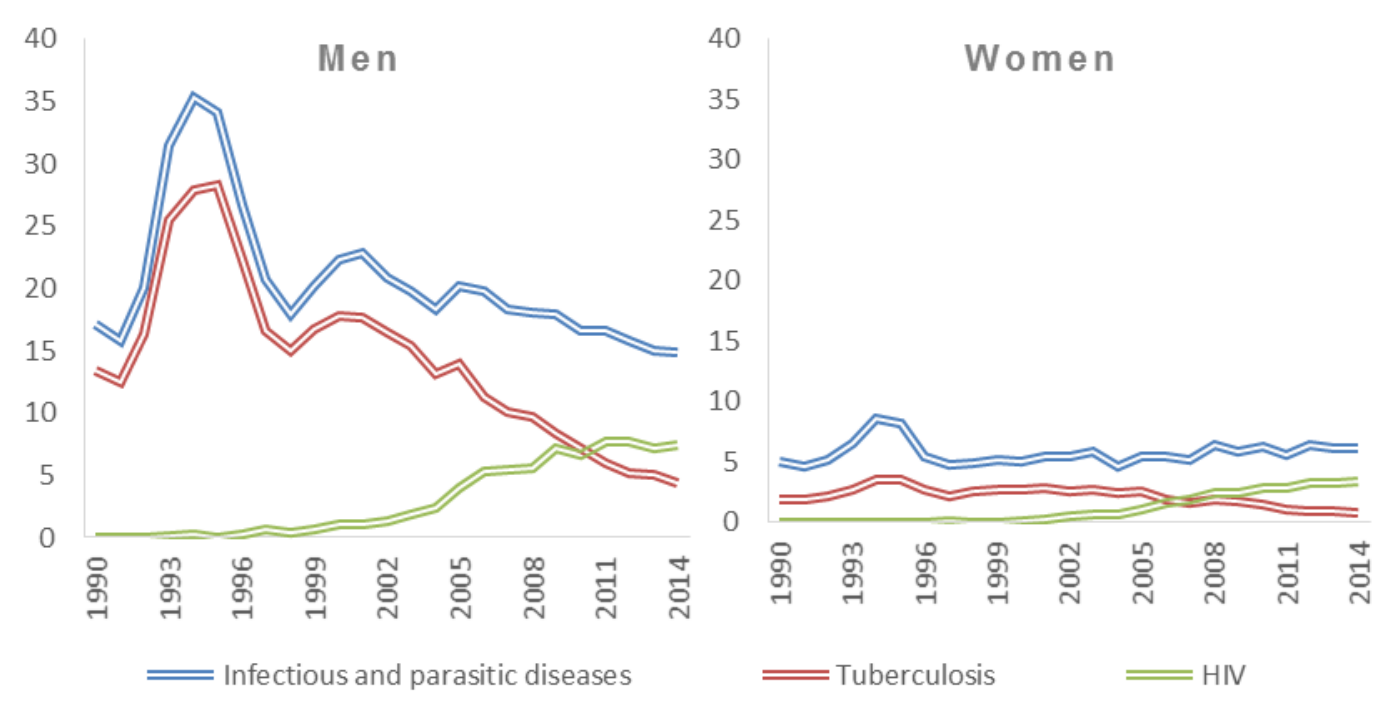

Figure 22. Standardised death rates from infectious and parasitic diseases, tuberculosis and HIV in Moscow, 1990-2014, per 100,000

Among men before the 2000s, the main contribution to mortality in this class came from tuberculosis (79\% in 1990). Then mortality from tuberculosis began to fall, as well as its contribution, which in 2014 came to $29 \%$. Among women, the proportion of tuberculosis was initially lower (37\% in 1990), but the decline in its contribution was also significant (up to $14 \%$ in 2014).

Deaths from the disease caused by the human immunodeficiency virus (HIV) have been recorded in Moscow since the early 1990s. The mortality level began to increase in 2000 among men and in 2005 among women. In 2014, the mortality rate from this cause in Moscow came to 7.4 per 100,000 for men and 3.4 for women, versus 11.3 and 4.9 nationally for men and women, respectively. The experts say that there are problems in the recording of morbidity and mortality from HIV infection [Pokrovsky 2004]. The rapid increase in mortality from HIV and the reduction in mortality from tuberculosis led to mortality from HIV exceeding mortality from tuberculosis among women in 2007 and among men in 2011. Now it is HIV which is the main contributor to mortality from infectious and parasitic diseases (in 2014, 50\% for men and 56\% for women).

The highest level of mortality from infectious and parasitic diseases among the megacities considered is observed in St. Petersburg, the lowest in Singapore (Figure 23).

As in Moscow, in St. Petersburg, Singapore and Hong Kong mortality from tuberculosis in 1990 contributed significantly to mortality from all infectious and parasitic diseases. By 2013, the contribution of this cause of death and mortality from it was at a low level in all megacities. As for mortality from HIV, the highest rate was observed in New York in 1997 (50 and 18 per 100,000 men and women, respectively). In other metropolitan areas, mortality was much lower. By 2013, the highest mortality rate from HIV among non-Russian megacities was also in New York City (9.6 and 4.0 per 100,000 men and women, respectively), which is higher than in Moscow. But in New York, in contrast to Moscow, the mortality rate from HIV is constantly decreasing. The situation is also alarming in St. Petersburg, where over a period of 14 years the level of mortality from HIV rose to 14.7 per 100,000 for men and 5.4 per 100,000 for women. 


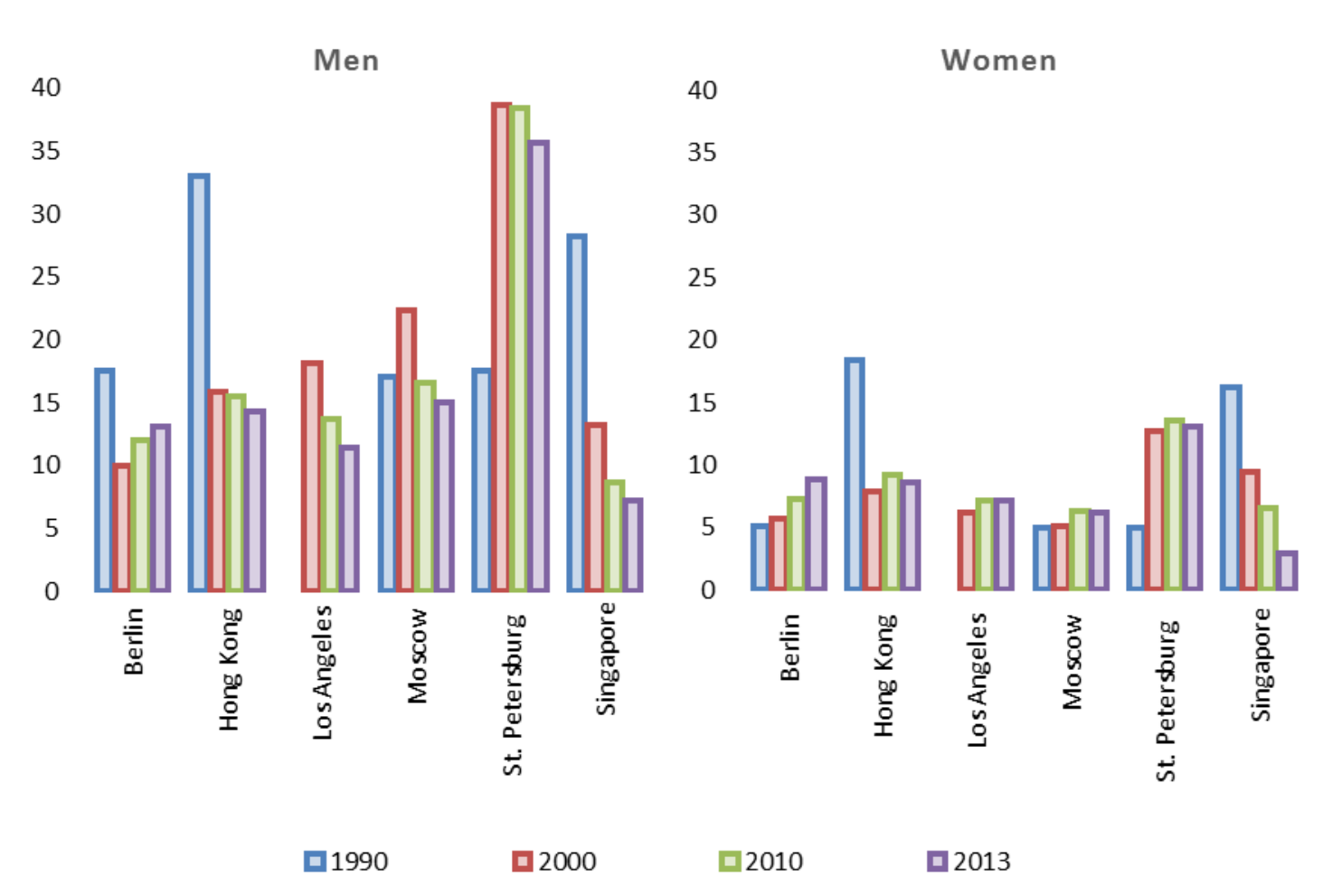

Figure 23. Standardised death rates from infectious and parasitic diseases in 6 megacities, 1990, 2000, 2010, 2013, per 100,000

Note: Los Angeles 2012.

\section{Diabetes}

Another cause to which special attention is paid in developed countries is diabetes. This is especially true in the USA, due to a strong growth in the number of people diagnosed with diabetes and to mortality from this cause. In Moscow, SDR from diabetes declined for almost two decades (Figure 24). But in the last three years for men (and the last two years for women) statistics have recorded an increase in mortality from this disease. Until 2011, mortality from this cause was higher among women, but starting in 2012 the men took the "lead". Higher mortality from diabetes among women is not particular to Moscow. It has also been observed in other megacities (Figure 25). After 2011, the death rate from diabetes (all forms) in Moscow increased slightly, the SDR rising among men by 1.3 times, among women by 1.1 times. In Russia as a whole, there is a more than twofold increase in the SDR from diabetes.

Mortality from diabetes in foreign megacities is much higher, and the proportion of deaths from this cause in some of them accounts for up to $4 \%$ of all deaths (Los Angeles, New York). 


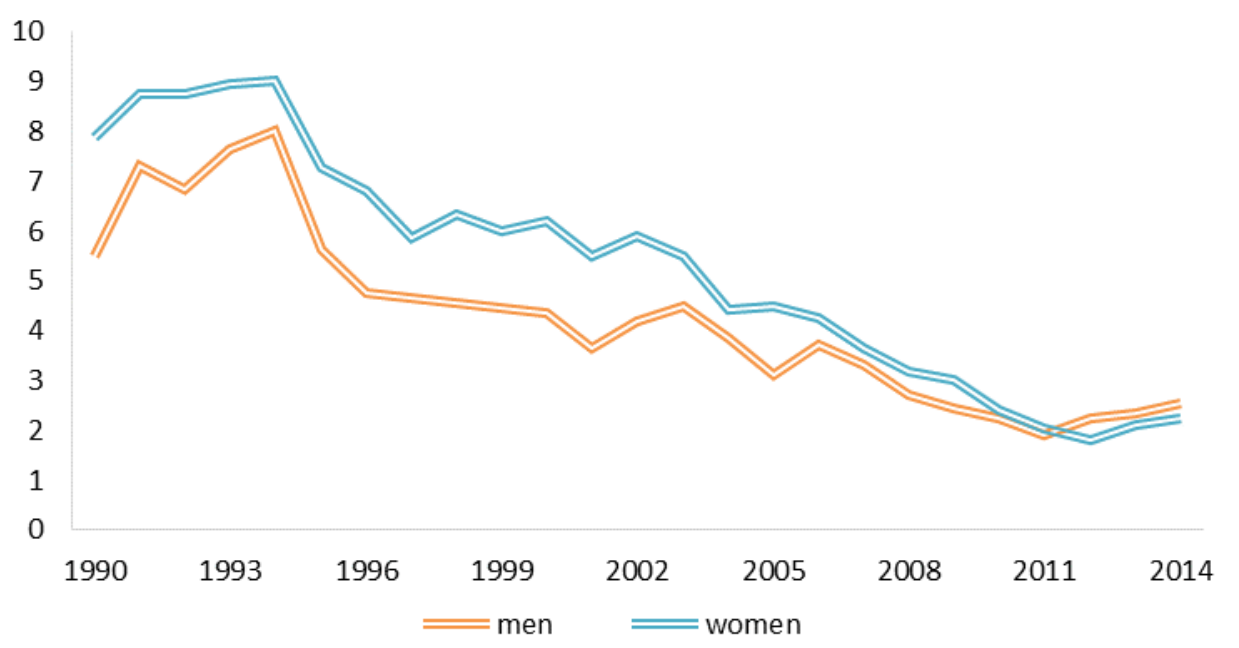

Figure 24. Standardised death rates from diabetes in Moscow, 1990-2014, per 100,000

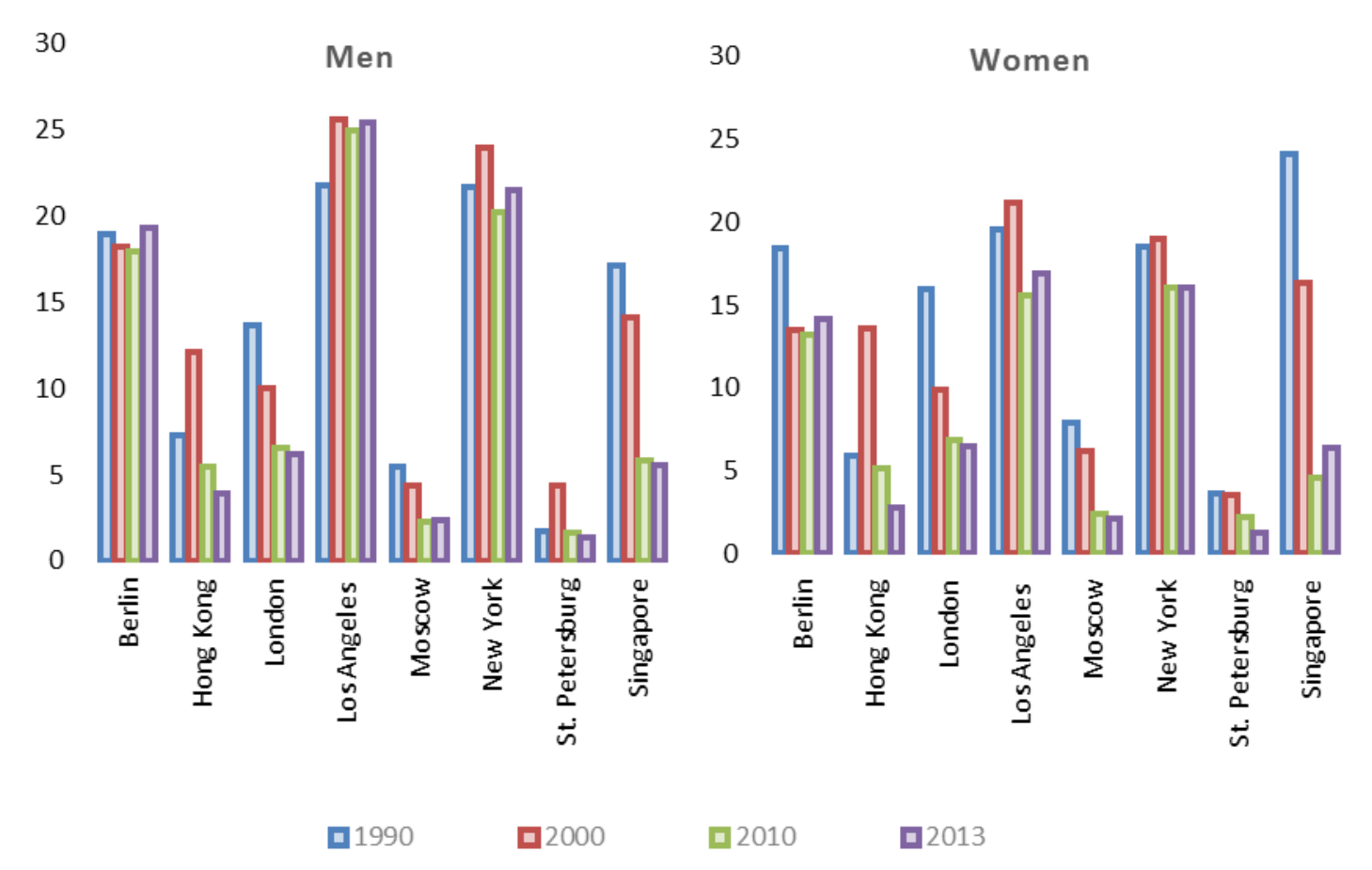

Figure 25. Standardised death rates from diabetes in 8 metropolitan areas, 1990, 2000, 2010, 2013, per 100,000

Note: New York 1997; Los Angeles 2012.

Most deaths from diabetes are among the elderly; they tend to have more than one disease. As in the case of pneumonia, the choice of the main cause of death depends on the practices prevailing in the country and region.

\section{Perinatal Mortality AND CONGenital ANOMAlies}

The vast majority of deaths from this group of causes are among children up to the age of 1 year, although congenital anomalies can also cause death among children over 1 year, as well as among the elderly. But the main share of deaths occurs in infancy. The proportion and level of mortality 
in this group of causes are an indirect indicator of maternal and child health, as well as of the availability and quality of health services for them. In Moscow, the mortality rate from these causes is the highest of all the cities examined, although in 1990 St. Petersburg was in first place (Figure 26). But in the mid-1990s, St. Petersburg managed to reduce this type of mortality. Now the level of mortality from causes of perinatal death and congenital anomalies in St. Petersburg is on a level comparable with US megacities, so that, in terms of infant mortality, St. Petersburg has for many years been the region with the lowest indicator.

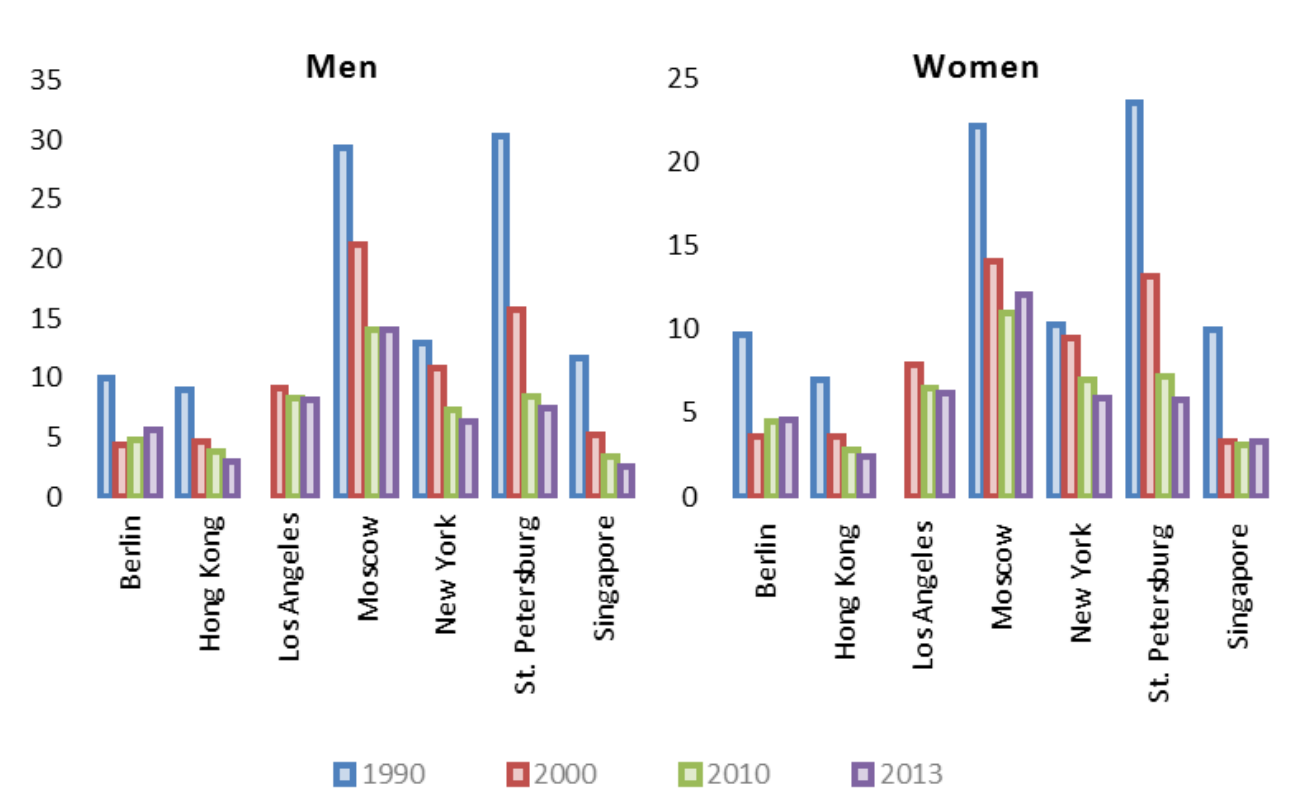

Figure 26. Standardised death rates by cause of perinatal mortality and congenital anomalies in 7 megacities, 1990, 2000, 2010, 2013, per 100,000

Note: New York 1997; Los Angeles 2012.

\section{CONCLUSIONS}

On the whole, from 1990 through 2014 the standardised death rates from all causes in Moscow have decreased by $44 \%$ for men and $42 \%$ for women (for $1990-2013$, by $43 \%$ and $41 \%$ respectively). The rate of the indicator's decline was higher than in many foreign cities, both overall and from some of the major causes of death (Table 13), largely due to a higher initial level of mortality.

However, the situation in Moscow in the first half of the 1990s was very unfavourable, so that, despite the relatively high rate of decline, the lag behind the other megacities remains, a slight decrease notwithstanding. As has been shown (Table 2), the SDR from all causes in Moscow in 2013 was significantly higher than in all the selected foreign cities. Moreover, for men it was higher than in those cities in 2000, and even than in some of them in 1990, which gives grounds to speak of a twenty-year lag in Moscow. For women, the results of such comparisons are only slightly better. 
Table 13. The reduction of standardised death rates of the most important classes of causes of death in 7 megacities of the world, 2013, in \% relative to 1990

\begin{tabular}{l|c|c|c|c}
\hline \multirow{2}{*}{ Megacity } & \multirow{2}{*}{ All causes } & \multicolumn{3}{|c}{ Including } \\
\cline { 3 - 5 } & & Cardiovascular diseases & Neoplasms & External causes \\
\hline \multirow{3}{*}{ Berlin } & & Men & & \\
Hong Kong & 59.1 & 40.3 & 78.1 & 60.9 \\
London & 61.4 & 49.0 & 68.2 & 69.5 \\
Moscow & 58.8 & 39.3 & 56.9 & 92.9 \\
St. Petersburg & 57.0 & 50.8 & 52.7 & 47.1 \\
Singapore & 72.1 & 70.1 & 66.9 & 66.1 \\
Tokyo & 55.7 & 45.4 & 69.3 & 48.9 \\
& 68.6 & 46.4 & 78.9 & 54.0 \\
Berlin & & Women & & \\
Hong Kong & 61.8 & 43.2 & 79.3 & 52.9 \\
London & 55.3 & 37.5 & 75.1 & 58.4 \\
Moscow & 69.1 & 47.7 & 74.8 & 98.9 \\
St. Petersburg & 58.6 & 52.2 & 68.8 & 43.0 \\
Singapore & 69.6 & 65.4 & 79.3 & 59.3 \\
Tokyo & 52.4 & 37.4 & 73.9 & 32.8 \\
\hline
\end{tabular}

Particularly unfavourable for Moscow is a comparison with foreign megacities of the levels of mortality from diseases of the circulatory system (Table 3). Here, not only is the current gap quite large, but Moscow's mortality level has not yet come close even to the level observed in foreign megacities in 1990, especially for men. The only city exceeding today's Moscow in mortality from cardiovascular diseases is Berlin in 1990, but at that time Berlin was still experiencing the lingering effects of the socialist way of life. The differences in mortality between the eastern and western parts of Germany had been almost entirely eliminated only by the end of the 1990's.

The differences in standardised death rates from cancer between Moscow and St. Petersburg, on the one hand, and foreign metropolises, on the other, are not so great (Table 4), but Moscow is the loser across the board. However, the gap in demographic losses between Moscow and foreign cities due to Moscow's higher death rate from cancer has not reached the same magnitude as in the case of cardiovascular diseases and external causes of death.

The situation with external causes of death is similar in many ways to that of diseases of the circulatory system. In Moscow, mortality from external causes affects a younger part of the population than in foreign megacities; as a result, its adverse effect on life expectancy is particularly high. Although the reduction in mortality from this (in large part preventable) cause was quite significant in Moscow after 2000, compared with foreign megacities the achievements of our capital to reduce this type of mortality seem rather paltry. For men, and sometimes women, it is several times higher than in London, New York, Tokyo or Berlin (Figure 14).

The standard of living and access to quality health care are greater in Moscow than in neighbouring areas, and the population of Moscow has significantly higher levels of education. It is therefore not surprising that Moscow is markedly different from the nearest Russian regions in terms of mortality from cardiovascular diseases and external causes. But the lower mortality from neoplasms, which is relatively stable over time and differs little between the regions of the country, prompts a search for possible explanations of the relatively low level of the capital's mortality [Andreev, Kvasha, Kharkov 2006]. However, even if we consider Moscow's mortality statistics 
reliable, compared with foreign megacities Moscow's success looks quite modest. As for similarities and differences in mortality between Moscow and foreign megacities, it must be admitted that there are as of yet more differences than similarities.

Nonetheless, Moscow's success in reducing mortality in the 2000-2014 period inspires a certain optimism, and the goal of getting close to the mortality rates of foreign megacities does not seem unattainable. The difficulty is in predicting just how events will develop in the deteriorating economic situation. It is useful to recall that during the crisis of the first half of the 1990s, Moscow completely lost all pre-existing advantages in mortality over neighbouring regions.

\section{REFERENCES}

Aksel E.M. (2009). Statistika zlokachestvennykh novoobrazovaniy zhenskikh polovykh organov [Statistics of malignant neoplasms of female genitals] // Opukholi zhenskoy reproduktivnoy sistemy [Women reproductive system tumors]. 1-2: 76-80.

Aksel E.M. (2012). Statistika zlokachestvennykh novoobrazovaniy zhenskoy polovoy sfery [Statistics of malignant neoplasms of the female genital sphere] // Onkoginekologiya [Gynecologic Oncology]. 1:18-23.

Andreev E.M. (2002). Vozmozhnye prichiny kolebaniy prodolzhitel'nosti zhizni v Rossii v 90-ye gody [Possible reasons of fluctuations in life expectancy in Russia in the 1990s] // Voprosy statistiki [Problems in statistics]. 11: 3-15.

Andreev E.M. (2016). Pravil'no li schitayut umershikh ot sluchaynykh otravleniy alkogolem? [Is number of deaths from accidental alcohol poisoning counted correctly?] // Demoscope Weekly. №673-674. URL: http://demoscope.ru/weekly/2016/0673/tema01.php (accessed: 26.02.2016).

Andreev E.M., E.A. Kvasha, T.L. Kharkova (2006). Osobye tochki na karte smertnosti [Special points on the map of mortality] // Naselenie Rossii 2003-2004. Odinnadtsatyy-dvenadtsatyy ezhegodnyy demograficheskiy doklad [The population of Russia 2003-2004. Eleventhtwelfth annual demographic report] / A.G. Vishnevsky, ed. Moscow: 298-305.

Andreev E.M., E.A. Kvasha, T.L. Kharkova (2013). Smertnost' i prodolzhitel'nost' zhizni [Mortality and life expectancy] // Naselenie Rossii 2010-2011. VoseMTadtsatyydevyatnadtsatyy ezhegodnyy demograficheskiy doklad [Population of Russia 2010-2011. Eighteenth-nineteenth annual demographic report] / A.G. Vishnevsky, ed. Moscow: Izd. dom Vysshey shkoly ekonomiki: 385-443.

Andreev E.M., E.A. Kvasha, T.L. Kharkova, S.A. Timonin (2015). Smertnost' i prodolzhitel'nost' zhizni [Mortality and life expectancy] // Naselenie Rossii 2013. Dvadtsat' pervyy ezhegodnyy demograficheskiy doklad [Population of Russia of 2013. The twenty-first annual demographic report] / S.V. Zakharov, ed. Moscow: Izd. dom Vysshey shkoly ekonomiki: 182-273.

Andreev E.M., V.M. Shkolnikov, W.A. Pridemore, S.Yu. Nikitina (2015). A method for reclassifying cause of death in cases categorized as "event of undetermined intent" // Population health metrics. 13, Art. 23. doi:10.1186/s12963-015-0048-y.

Danilova I.A. (2015). Osobennosti postroeniya nepreryvnykh ryadov pokazateley smertnosti po prichinam smerti v Rossii [Features of the construction of a continuous series of mortality by causes of death in Russia] // Voprosy statistiki [Problems in statistics]. 11: 58-68. 
Demograficheskaya modernizatsiya Rossii: 1900-2000 [Demographic modernization of Russia: 1900-2000] (2006) / A.G. Vishnevsky, ed. Moscow: Novoe izdatel'stvo.

Fattakhov T.A. (2015). Dorozhno-transportnye proisshestviya i smertnost' v Rossii: 1956-2012 [Road traffic accidents and mortality in Russia: 1956-2012] // Demograficheskoe obozrenie [Demographic review]. 2: 6-36 (accessed: 26.02.2016).

Ivanova A.E., T.P. Sabgaida, V.G. Semenova, V.G. Zaporozhenko, E.V. Zemlianova, S.Iu. Nikitina (2013). Faktory iskazheniya struktury prichin smerti trudosposobnogo naseleniya Rossi [Factors distorting the structure of causes of death of the working-age population of Russia] // Sotsial'nye aspekty zdorov'ya naseleniyai [Social aspects of population health]. 4(32) URL: http://vestnik.mednet.ru/content/view/491/30/lang,ru/ (accessed: 26.02.2016).

Merabishvili V.M. (2013). Analiticheskaya epidemiologiya raka zheludka [Analytical epidemiology of gastric cancer] // Voprosy onkologii [Problems in oncology]. 59(5): 565.

Merabishvili V.M., N.G. Petrova, A.V. Atrochshenko, M.V. Kharitonov (2014). Analiz zabolevaemosti i smertnosti muzhskogo naseleniya ot raka predstatel'noy zhelezy (populyatsionnoe issledovanie) [An analysis of the incidence of and mortality from prostate cancer in the male population (population study)] // Kreativnaya onkologiya i khirurgiya. Elektronnyy nauchno-prakticheskiy zhurnal [Creative oncology and surgery]. 2. URL: http://eoncosurg.com/analiz-zabolevaemosti-i-smertnosti-muzhskogo-naseleniya-ot-rakapredstatelnoj-zhelezy-populyatsionnoe-issledovanie (accessed: 26.02.2016).

Oganov R.G., V.V. Konstantinov, T.N. Timofeeva, A.V. Kapustina, A.D. Deev, S.A. Shal'nova, I.E. Koltunov, Iu.A. Balanova, I.N. Lel'chuk (2011). Epidemiologiya arterial'noy gipertonii v Rossii. Rezul'taty federal'nogo monitoringa 2003-2010 gg. [Epidemiology of arterial hypertension in Russia. the federal monitoring results of 2003-2010] // Kardiovaskulyarnaya terapiya i profilaktika [Cardiovascular therapy and prevention]. 1: 9-13.

Pokrovsky V.V. (2004). Sotsial'no znachimye infektsii v XXI veke [Socially important infections in the XXI century] // Narodonaselenie [Population]. 3: 93-96.

Revich B.A., M. Podolnaia, E. Aksel, T.L. Kharkova, E.A. Kvasha (2014). Osobennosti onkologicheskoy zabolevaemosti i smertnosti trudosposobnogo naseleniya Moskvy [Distinctive features of cancer incidence and mortality in the working age population of Moscow] // Profilakticheskaya meditsina [Preventive medicine]. 7 (5): 31.

Semenova V.G., O.I. Antonova (2007). Dostovernost' statistiki smertnosti (na primere smertnosti ot travm i otravleniy v Moskve) [The validity of the mortality statistics (using the example of mortality from injury and poisoning in Moscow)] // Sotsial'nye aspekty zdorov'ya naseleniya. Elektronnyy nauchnyy zhurnal [Social aspects of population health]. 2(7). URL: http://vestnik.mednet.ru/content/view/28/30/ (accessed: 26.02.2016).

Shaposhnikov D., B. Revich, T. Bellander, G.B. Bedada, M. Bottai, T.L. Kharkova, E.A. Kvasha, E. Lezina, T. Lind, E. Semutnikova, G. Pershagen (2014). Mortality related to air pollution from the Moscow heat wave and wildfire of 2010 // Epidemiology. 25 (3): 359-364.

Shkolnikov V., M. McKee., D.A. Leon (2001). Changes in life expectancy in Russia in the mid1990s // The Lancet. 357(9260): 917-921. doi:10.1016/S0140-6736(00)04212-4.

Shkolnikov V.M., E.M. Andreev, M. McKee, D.A. Leon (2014). Rost prodolzhitel'nosti zhizni v Rossii 2000-kh godov [The growth in life expectancy in Russia in the 2000s] // Demograficheskoe obozrenie [Demographic review]. 1(2): 5-37. URL: https://demreview.hse.ru/data/2014/11/20/1101110530/DemRev_1_2_2014_5-37.pdf (accessed: 26.02.2016). 
Sostoyanie onkologicheskoy pomoshchi naseleniyu Rossii v 2014 godu [State oncological assistance to the population of Russia in 2014] (2015) / A.D. Kaprin, V.V. Starinskii, G.V. Petrova, eds. Moscow: MTIOI im. P.A. Gertsena.

UN (2015). World urbanization prospects: The 2014 revision. New York: United Nations.

Vasin S.A. (2015). Smertnost' ot povrezhdeniy s neopredelennymi namereniyami v Rossii i v drugikh stranakh [Deaths from injury with uncertain intent in Russia and in other countries] // Demograficheskoe obozrenie [Demographic review]. 1:92. URL:

http://demreview.hse.ru/data/2015/10/22/1079399391/DemRev_2_1_2015_89-124.pdf (accessed: 26.02.2016).

VOZ (2015). Virus papillomy cheloveka (VPCh) i rak sheyki matki [Human papillomavirus (HPV) and cervical cancer] // Informatsionnyy byulleten' [Bulletin of the World Health Organization].380. URL: http://www.who.int/mediacentre/factsheets/fs380/ru/ (accessed: 26.02.2016).

Waterhouse J., C.S. Muir, P. Correa, J. Powell, eds. (1976). Cancer incidence in five continents. Lyon: IARC. 3: 456.

WHO (2014). Comprehensive cervical cancer control. A guide to essential practice. Second edition.

Wroblewski L.E., R.M. Peek, Jr. Wilson, K.T. Wilson (2010). Helicobacter pylori and gastric cancer: factors that modulate disease risk // Clinical microbiology reviews. 23 (4): 713-739. 